\title{
Upside down: 'Cryobatrachus' and the lydekkerinid record from Antarctica
}

\author{
Bryan M. Gee, ${ }^{1 *}$ (1) Peter J. Makovicky, ${ }^{2}$ and Christian A. Sidor ${ }^{1}$ \\ ${ }^{1}$ Burke Museum and Department of Biology, University of Washington, Seattle, WA 98195, USA <bmgee@uw.edu>, <casidor@uw.edu> \\ ${ }^{2}$ Department of Earth and Environmental Sciences, University of Minnesota, Minneapolis, MN 55455, USA < pmakovic@ umn.edu>
}

\begin{abstract}
Temnospondyl amphibians are common in non-marine Triassic assemblages, including in the Fremouw Formation (Lower to Middle Triassic) of Antarctica. Temnospondyls were among the first tetrapods to be collected from Antarctica, but their record from the lower Fremouw Formation has long been tenuous. One taxon, 'Austrobrachyops jenseni,' is represented by a type specimen comprising only a partial pterygoid, which is now thought to belong to a dicynodont. A second taxon, 'Cryobatrachus kitchingi,' is represented by a type specimen comprising a nearly complete skull, but the specimen is only exposed ventrally, and uncertainty over its ontogenetic maturity and some aspects of its anatomy has led it to be designated as a nomen dubium by previous workers. Here, we redescribe the holotype of ' $C$. kitchingi,' an undertaking that is augmented by tomographic analysis. Most of the original interpretations and reconstructions cannot be substantiated, and some are clearly erroneous. Although originally classified as a lydekkerinid, the purported lydekkerinid characteristics are shown to be unfounded or no longer diagnostic for the family. We instead identify numerous features shared with highly immature capitosaurs, a large-bodied clade documented in the upper Fremouw Formation of Antarctica and elsewhere in the Lower Triassic. Additionally, we describe a newly collected partial skull from the lower Fremouw Formation that represents a relatively mature, small-bodied individual, which we provisionally refer to Lydekkerinidae; this specimen represents the most confident identification of a lydekkerinid from Antarctica to date.
\end{abstract}

\section{Introduction}

Temnospondyl amphibians have been documented from the Fremouw Formation exposures of Antarctica for several decades (Barrett et al., 1968; Colbert and Cosgriff, 1974; Cosgriff and Hammer, 1984; Sidor et al., 2007, 2008, 2014) and are a crucial component of the broader terrestrial (non-marine) assemblage for understanding the recovery of tetrapods following the endPermian mass extinction (e.g., Yates and Warren, 2000; Ruta and Benton, 2008; Tarailo, 2018). However, fossils from the informally recognized lower member of the Fremouw Formation (Lower Triassic) are fragmentary and often of dubious identification. The first temnospondyl to be named from the lower Fremouw, 'Austrobrachyops jenseni' Colbert and Cosgriff, 1974, was described as a brachyopid based on a pterygoid that is now accepted to be, at minimum, not a temnospondyl, and is perhaps a dicynodont (e.g., Warren and Marsicano, 2000). The second taxon to be named from the lower Fremouw, 'Cryobatrachus kitchingi' Colbert and Cosgriff, 1974, was described as a lydekkerinid based on a more substantial holotype that is an uncontroversial temnospondyl (Colbert and Cosgriff, 1974; Figs. 1, 2). However, this specimen consists of a skull roof

*Corresponding author. preserved in ventral view, thereby obscuring key details about ornamentation and negating a direct comparison to the sutural patterns in dorsal view as is typically used for comparative anatomy. More recent workers, including Schoch and Milner (2000), who suggested that it also could be a juvenile of a large-bodied capitosaur or trematosaur, have cast doubt on its lydekkerinid affinities (e.g., Jeannot et al., 2006; Hewison, 2007; Sidor et al., 2007; Dias-da-Silva and Hewison, 2013).

The present undertaking to re-describe the holotype of 'Cryobatrachus kitchingi' is motivated by several developments. Firstly, the osteological understanding and phylogenetic framework of temnospondyls have both been greatly improved since its initial description. Lydekkerinid anatomy and taxonomy have been substantially revised, particularly for Karoo Basin taxa (Shishkin et al., 1996; Pawley and Warren, 2005; Jeannot et al., 2006; Hewison, 2007, 2008). Key among this is the recognition of wider intraspecific and taphonomic variation within the eponymous Lydekkerina huxleyi (Lydekker, 1889), than was previously recognized (Jeannot et al., 2006; but see Hewison, 2007, for dissent). Secondly, the datedness of the original description of ' $C$. kitchingi' renders it impossible to assess the interpreted sutures from the literature, but the sutures are obviously of great import for assessing phylogenetic relationships. Thirdly, although ontogeny remains poorly understood in most large-bodied temnospondyls, data published subsequent 


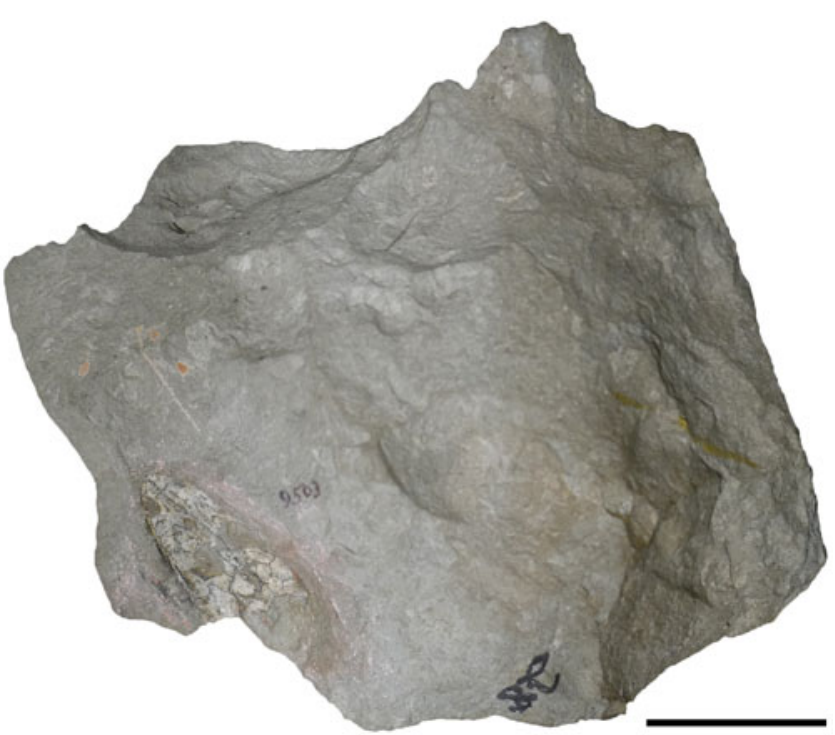

Figure 1. Photograph of the entire block containing AMNH FARB 9503 (Cryobatrachus kitchingi). Scale bar $=5 \mathrm{~cm}$.

to the naming of ' $C$. kitchingi' can inform the differentiation of small-bodied adults from small-bodied juveniles, such as studies of capitosaur ontogeny (Welles and Cosgriff, 1965; Warren and
Hutchinson, 1988, 1990b; Warren and Schroeder, 1995; Steyer, 2003). Finally, recent collecting in the lower and middle Fremouw recovered substantial amounts of well-preserved, smallbodied temnospondyl material. Gee and Sidor (2021) recently identified some of the material from the lower Fremouw as belonging to Micropholis stowi Huxley, 1859, a taxon long known from the Lystrosaurus declivis Assemblage Zone (LAZ) in South Africa (Schoch and Rubidge, 2005), but other specimens undoubtedly belong to other clades. It would be similarly intuitive for a lydekkerinid, if not $L$. huxleyi specifically (which also occurs in Australia; Warren et al., 2006), to occur in the lower Fremouw, even if not in the form of ' $C$. kitchingi.' This study presents a re-description of ' $C$. kitchingi' alongside a recently collected specimen from the lower Fremouw that we interpret as a lydekkerinid.

\section{Materials and methods}

Materials.-This study focuses on the holotype of 'Cryobatrachus kitchingi' (AMNH FARB 9503; Fig. 1), but there are 20 referred specimens described by Colbert and Cosgriff (1974, p. 20) and Cosgriff and Hammer (1984), with an additional three referred only to 'Cryobatrachus sp.' We do not address the referred material here because almost all of it lacks skeletal overlap with the holotype or was collected from
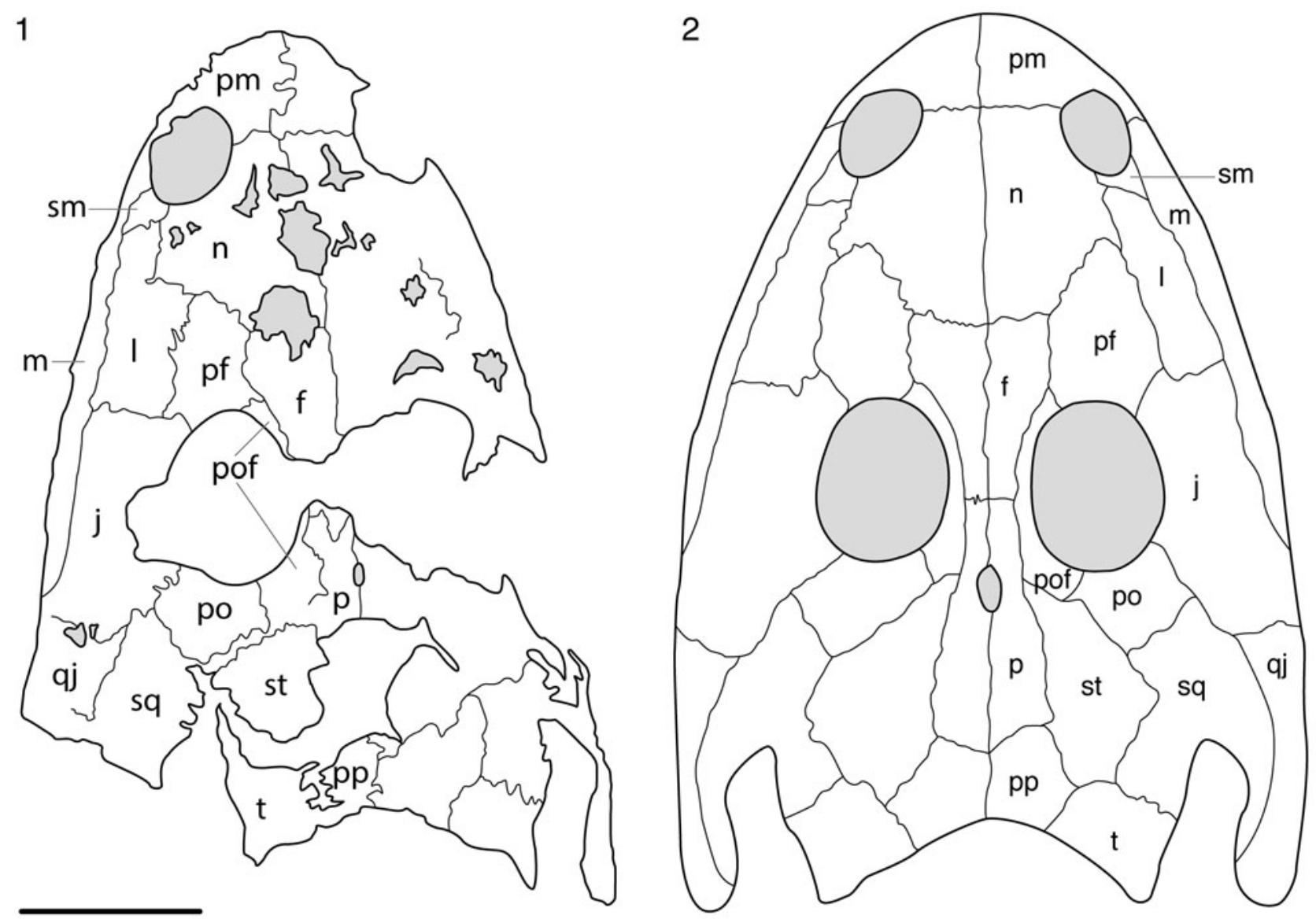

Figure 2. Reproduced interpretative line drawing and reconstruction of AMNH FARB 9503 ('Cryobatrachus kitchingi') from Colbert and Cosgriff (1974). (1) Interpretative line drawing; (2) reconstruction. Abbreviations: f, frontal; j, jugal; 1, lacrimal; m, maxilla; n, nasal; p, parietal; pf, prefrontal; pm, premaxilla; po, postorbital; pof, postfrontal; pp, postparietal; qj, quadratojugal; sm, septomaxilla; sq, squamosal; st, supratemporal; t, tabular. Scale bar $=1 \mathrm{~cm}$. 
a different locality, and conspecificity is not well supported. The holotype is from Kitching Ridge on the Shackleton Glacier, but neither the paratype (AMNH FARB 9556) nor any other material referred to the species level was collected from this site. The precise stratigraphic position of the type locality is unknown, but Collinson et al. (2006) reported that most vertebrates collected in 1970 came from within the first $50 \mathrm{~m}$ of the lower Fremouw. Peecook et al. (2019) provide a recent review of lower Fremouw vertebrate localities.

All of the referred material is highly fragmentary and isolated; it is therefore not sufficient to erect a novel taxon (and no previous worker has suggested as much), and it cannot re-validate 'C . kitchingi' if the holotype proves to be undiagnostic. Schoch and Milner (2000, p. 165) argued that some of this material (unspecified) is "clearly genuine" lydekkerinid material. However, it is worth noting that none of the referred material other than the paratype preserves a skeletal region in which lydekkerinid apomorphies are preserved (even under Schoch and Milner's diagnosis) - most referred material is from the lower jaw or the postcranial skeleton - and therefore, any referral would be predicated on resemblance-based identification only. For this reason, the occurrence of lydekkerinids in Antarctica based on material published to date should be considered tenuous at best.

It also bears noting that Colbert and Cosgriff's (1974) use of 'referred specimen' differs from modern practices in which their act of referral with reservations is closer to the more tentative 'cf.' designation. Those authors instead used the 'paratype' designation for more confidently referred material, which is a less-common designation in contemporary practice. Colbert and Cosgriff's (1974) designations are, however, consistent with the contemporary provisions of the International Commission on Zoological Nomenclature (ICZN, 1999, Article 72) in which the paratype is a confidently referred specimen in the type series, and 'referred specimens' are more tenuously referred specimens that are excluded from the type series. This shift in terminology thus accounts for the contradictory referral of numerous specimens with no skeletal overlap with the holotype and Colbert and Cosgriff's (1974) repeated statements that the material was confidently referable to small lydekkerinids, but not necessarily to ' $C$. kitchingi' specifically. It also accounts for the disparity in apparent confidence in the referral of two different suites of material (Colbert and Cosgriff, 1974, p. 20).

The single paratype (AMNH FARB 9556) is a natural mold of a small fragment from the posterior skull table (AMNH FARB 9556), from which a peel was produced to show ornamentation that was purportedly like that of Lydekkerina Broom, 1915. This mold is of questionable conspecificity with the holotype, whose ornamentation is not exposed, because recent diagnoses of Lydekkerinidae (both phenetic and phylogenetic; Jeannot et al., 2006; Hewison, 2007; Eltink et al., 2019) do not include a distinct ornamentation style (i.e., there is no diagnostic lydekkerinid-type ornamentation, only a generic style found in most lydekkerinids). Furthermore, Colbert and Cosgriff's (1974, p. 24) characterization of Lydekkerina-like ornamentation ("pitted over their entire surfaces without the grooving seen in many other labyrinthodont amphibians") is both generic and inaccurate. Lydekkerina does in fact have some lateral line grooves (e.g., Jeannot et al., 2006). Caution also should be exercised with characterizations of 'typical' ornamentation, especially when it is not a highly distinctive form (e.g., the pustulated ornamentation of Micropholis stowi, the 'spider-web' pattern of rhytidosteids; Schoch and Rubidge, 2005; Dias-da-Silva and Marsicano, 2011) because ornamentation can also be intraspecifically variable (e.g., Morkovin, 2015; Antczak and Bodzioch, 2018). The preserved outline of an otic notch with a posteriorly projecting tabular horn is also not diagnostic of Lydekkerinidae. Like the 'referred specimens,' conspecificity of the paratype with the holotype of ' $C$. kitchingi' was thus predicated entirely on the interpretation of both specimens as a lydekkerinid and the assumption that only one lydekkerinid was present (which is demonstrably not true in the LAZ).

The holotype is a nearly complete skull roof, without any palatal or neurocranial elements, preserved in ventral view. The specimen itself measures only $\sim 4.5 \mathrm{~cm}$ along the midline, but it is embedded in a sizeable block $(\sim 20 \mathrm{~cm}$ long by 17.5 $\mathrm{cm}$ wide and $7-8 \mathrm{~cm}$ thick in some areas), which is shown here in Figure 1 to demonstrate that the actual fossil occupies very little of this volume. The bone surface is undamaged in most areas, but in a few spots on the posterior skull table, the ornamentation is semi-discernible, indicating weathering through to the dorsal surface. The sutures interpreted by Colbert and Cosgriff (1974) were drawn on the specimen with permanent marker, although they were apparently added after the specimen was photographed for their study.

A newly described specimen, FMNH PR 5020, is a recently collected partial skull from exposures of the lower Fremouw Formation, Collinson Ridge, Shackleton Glacier. It was collected by P.J.M. at $85^{\circ} 13^{\prime} 04.4^{\prime \prime} \mathrm{S}$, W175 $16^{\prime} 06.4^{\prime \prime} \mathrm{W}$, near the top of the exposed outcrop, but likely within the lower half of the lower Fremouw overall. The fossil is preserved anteriorly and more complete on the left side and exposed dorsally. A large number of unassociated archosauromorph postcranial elements overlie parts of the skull.

Photography.-Photographs of FMNH PR 5020 were taken at the Burke Museum by Mike Rich using a Canon EOS 5DS camera with a $100 \mathrm{~mm}$ macro lens; photographs of AMNH FARB 9503 were taken by BMG using the same setup. Figures were compiled using Adobe Photoshop and Illustrator.

Computed tomography.-AMNH FARB 9503 was scanned at the University of Texas, Austin CT lab (UTCT) by Matt Colbert with post-reconstruction ring correction applied by Jessie Maisano using an NSI scanner at $150 \mathrm{kV}$ and $0.24 \mathrm{~mA}$. The scan produced 1,548 slices with an isometric voxel size of $26.3 \mu \mathrm{m}$. Data were downsampled to 8-bit and adjusted for brightness and contrast in ImageJ before being processed in Avizo Lite 9.2. The raw data (16-bit TIFF files) and additional details on the scan and post-processing are available on MorphoSource (Media \#000367915); permission to download must be obtained upon reasonable direct request to the Director of Collections at the American Museum of Natural History. Full details regarding use of scan data of AMNH specimens is available on the museum's website (https://www. amnh.org/research/paleontology/3d-scanning).

The tomographic analysis was complicated by the large volume of the encapsulating block; AMNH FARB 9503 takes up only a small surface area (Fig. 1). While the achievable 
resolution was fairly good $(26.3 \mu \mathrm{m})$, the contrast between the fossil and the matrix is relatively low. It becomes increasingly poor towards the interior of the block (the anatomical left side of the skull) and in the posterior skull, such that the fossil is barely discernible or poorly resolved (Fig. 3.1, 3.2). As a result, we were faced with the option to either increase the contrast of the raw data, resulting in the loss of edges and some surfaces, but a greater ease and confidence in separation of the well- resolved regions of the fossil (Fig. 3.2, 3.4, 3.6); or to retain the lower contrast in order to maintain the edges and poorly resolved regions of the entire scanned area, but at the expense of being able to segment out the fossil (Fig. 3.1, 3.3, 3.5). We elected for the former in the hopes of obtaining a few details that would require high fidelity segmentation (e.g., ornamentation), but this came at the expense of the surface of the posterior skull, which is very poorly resolved (Fig. 3.1, 3.2). Different

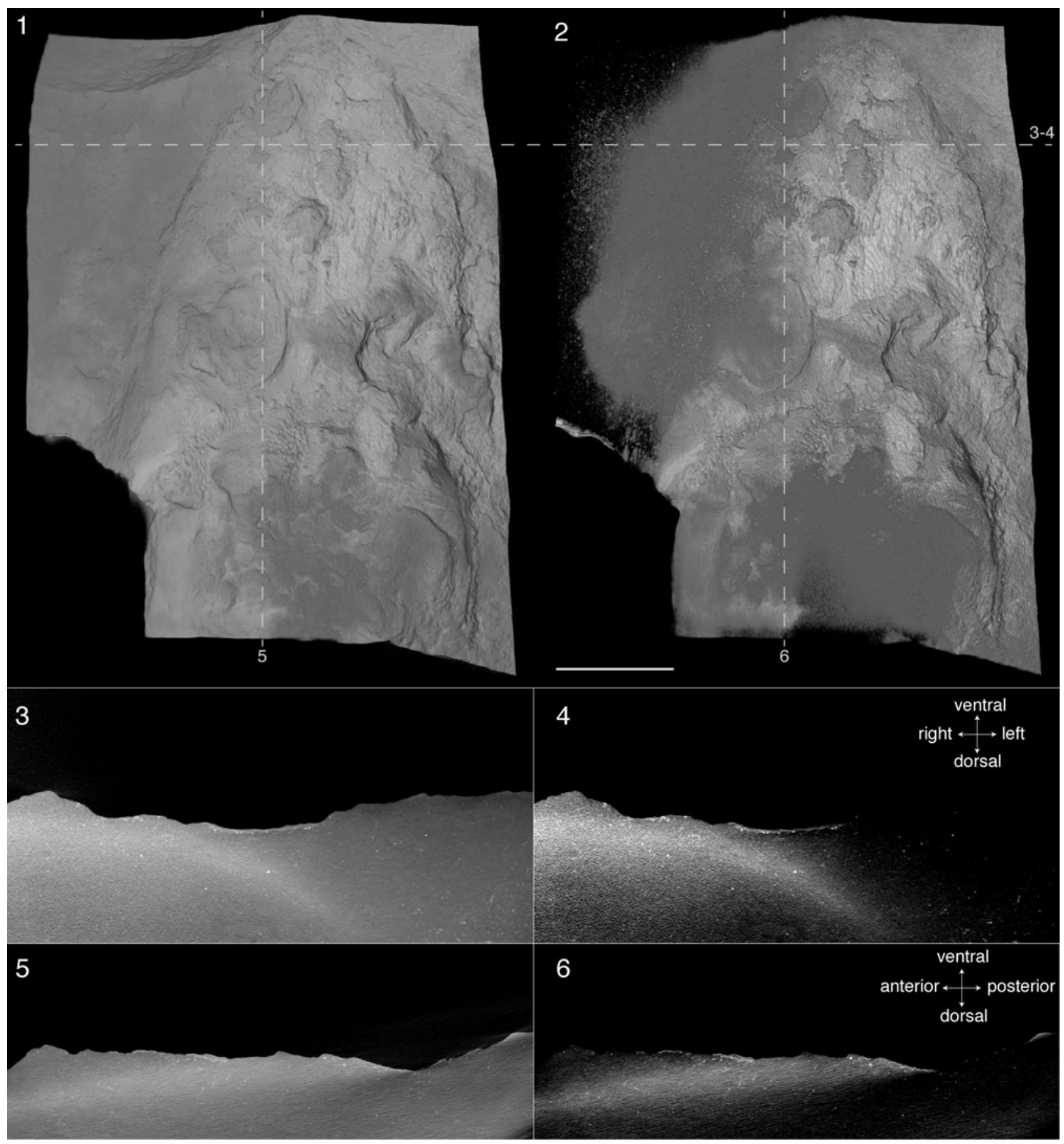

Figure 3. Comparison of surface fidelity and fossil-matrix contrast differentiation at two different brightness-contrast settings for the tomographic analysis of AMNH FARB 9503 ('Cryobatrachus kitchingi'). (1) Volume rendering of the scanned region at a low contrast setting; (2) the same at a high contrast setting; (3) digital transverse section from the low-contrast dataset; (4) the same section from the high-contrast dataset; (5) digital sagittal section from the low-contrast dataset; (6) the same from the high-contrast dataset. Dashed lines in $\mathbf{1}$ and $\mathbf{2}$ indicate the digital planes of section for parts 3-6. Scale bar $=1 \mathrm{~cm}$. 
parts of the skull that could be rendered had to be segmented using drastically different grayscale thresholds-over the 8-bit range of $0-255$, segmenting was done between 1 and 230 . Therefore, the evenness and level of detail of edges and surfaces are not consistent. Contrast was not sufficient to positively identify sutures (e.g., by identification of interdigitations) in most regions of the skull — only slight gaps between elements that were already externally observable (some of which are undoubtedly taphonomic breaks) could be resolved.

Phylogenetic analysis.-We originally did not perform a phylogenetic analysis to test the position of these specimens for several reasons. The first is that AMNH FARB 9503 is not assuredly mature, which would possibly compromise any analysis seeking to demonstrate affinities with a particular clade because it may lack apomorphies only found in adults of a given clade. If this specimen is a juvenile of a typically large-bodied stereospondyl clade, it might experience stemward slippage away from these clades and towards the base of Stereospondyli where predominantly small- to medium-sized clades are recovered (e.g., Lydekkerinidae, Rhinesuchidae, Rhytidosteidae). The second is that both specimens are incomplete and crucially lack information on most of the sutures, which make up the majority of cranial phylogenetic characters. The third is that small-bodied temnospondyls (e.g., Lapillopsis nana Warren and Hutchinson, 1990 [Warren and Hutchinson, 1990a]; Rileymillerus cosgriff Bolt and Chatterjee, 2000), whether represented by putative adults or only by immature specimens, have proven to be frequent wildcard taxa, with unstable positions within and between analyses (e.g., McHugh, 2012; Schoch, 2013; Pardo et al., 2017; Eltink et al., 2019). Many small-bodied taxa are often unsampled in temnospondyl- or stereospondyl-wide phylogenetic analyses (e.g., Balanerpeton woodi Milner and Sequeira, 1993; the rhytidosteid Nanolania anatopretia Yates, 2000; the dvinosaurs Eugyrinus wildi [Woodward, 1891] and Thabanchuia oomie Warren, 1998 [Warren, 1998a]; the brachyopid Notobrachyops picketti Cosgriff, 1973; the possible trematosaur Almasaurus habbazi Dutuit, 1976), and certain peculiar topologies (e.g., the clustering of $L$. nana with dissorophoids) may be merely an artifact of convergent small size (Schoch, 2013; Pardo et al., 2017).

Nonetheless, we present the results of a preliminary phylogenetic analysis here, as requested by the reviewers. We analyzed both specimens separately in the most recent version of Schoch's (2013) temnospondyl-wide matrix (Schoch et al., 2020). This matrix was selected because of its wide taxonomic coverage, which mitigates any preconceived notions of taxonomic affinities (e.g., to Stereospondyli). We omitted the lissamphibians and lepospondyls included in the original matrix since the question of lissamphibian origins is irrelevant to the position of the Antarctic temnospondyls discussed here. Two OTUs were scored for AMNH FARB 9503: one based on the interpretations of Colbert and Cosgriff (1974) and one based on our revised interpretations. We also added several small-bodied Triassic stereospondyls that share some features with these specimens: the rhinesuchid Broomistega putterilli Shishkin and Rubidge, 2000 (Broom, 1930; Shishkin and Rubidge, 2000); the rhytidosteid Nanolania anatopretia (Yates, 2000); the putative rhytidosteid Laidleria gracilis Kitching, 1958 (Warren, 1998b; Dias-da-Silva and Marsicano, 2011); the putative trematosaur Almasaurus habbazi; the lydekkerinid Chomatobatrachus halei Cosgriff, 1974 (Warren et al., 2006); and the lapillopsids Lapillopsis nana and Rotaurisaurus contundo Yates, 1999. Broomistega putterilli, C. halei, Lai. gracilis, and Lap. nana were originally scored by Schoch (2013), but either were excluded from the final analysis of that study, or were not sampled at all in the analysis of Schoch et al. (2020). Schoch's (2013) scores for these four taxa were retained by Pardo et al. (2017); their scores are expanded here for the additional 15 characters added to this matrix by Schoch et al. (2020). Our analysis was performed in PAUP* $4.0 b 169$ (Swofford, 2002), with Greererpeton burkemorani Romer, 1969, and Proterogyrinus scheelei Romer, 1970, as the operational outgroups, a heuristic search using 10,000 random-addition sequence replicates (holding one tree per step), and tree bisection-and-reconnection (TBR). Bootstrapping was performed using 10,000 fast stepwise addition replicates. All characters were equally weighted and unordered following previous iterations of this matrix (Schoch, 2013; Pardo et al., 2017; Schoch et al., 2020).

Repository and institutional abbreviations.-AMNH FARB, American Museum of Natural History (Fossil Amphibians, Reptiles, and Birds collections), New York, NY, USA; FMNH, Field Museum of Natural History, Chicago, IL, USA; UWBM, University of Washington Burke Museum, Seattle, WA, USA; WSUVP, Wayne State University, Vertebrate Paleontology Collection, Detroit, MI, USA.

\section{Systematic paleontology}

Order Temnospondyli Zittel, 1888

Suborder Stereospondyli Zittel, 1888

Clade cf. Capitosauria Yates and Warren, 2000, sensu Schoch, 2008

'Cryobatrachus' Colbert and Cosgriff, 1974

Type species.-Cryobatrachus kitchingi Colbert and Cosgriff, 1974, from the lower Fremouw Formation at Kitching Ridge, Antarctica, Shackleton Glacier, by original designation.

$$
\begin{gathered}
\text { 'Cryobatrachus kitchingi' } \begin{array}{c}
\text { Colbert and Cosgriff, 1974, nomen } \\
\text { dubium } \\
\text { Figures } 1-5
\end{array} \\
\text { ig }
\end{gathered}
$$

1974 Cryobatrachus kitchingi Colbert and Cosgriff, p. 19, figs. 14-19.

1984 Cryobatrachus kitchingi Cosgriff and Hammer, p. 53, fig. 4.

2000 "juvenile capitosaur or benthosuchid" Schoch and Milner, p. 165.

2007 Stereospondyli incertae sedis Hewison, p. 53

Holotype.-AMNH FARB 9503, nearly complete skull roof visible in internal view. 


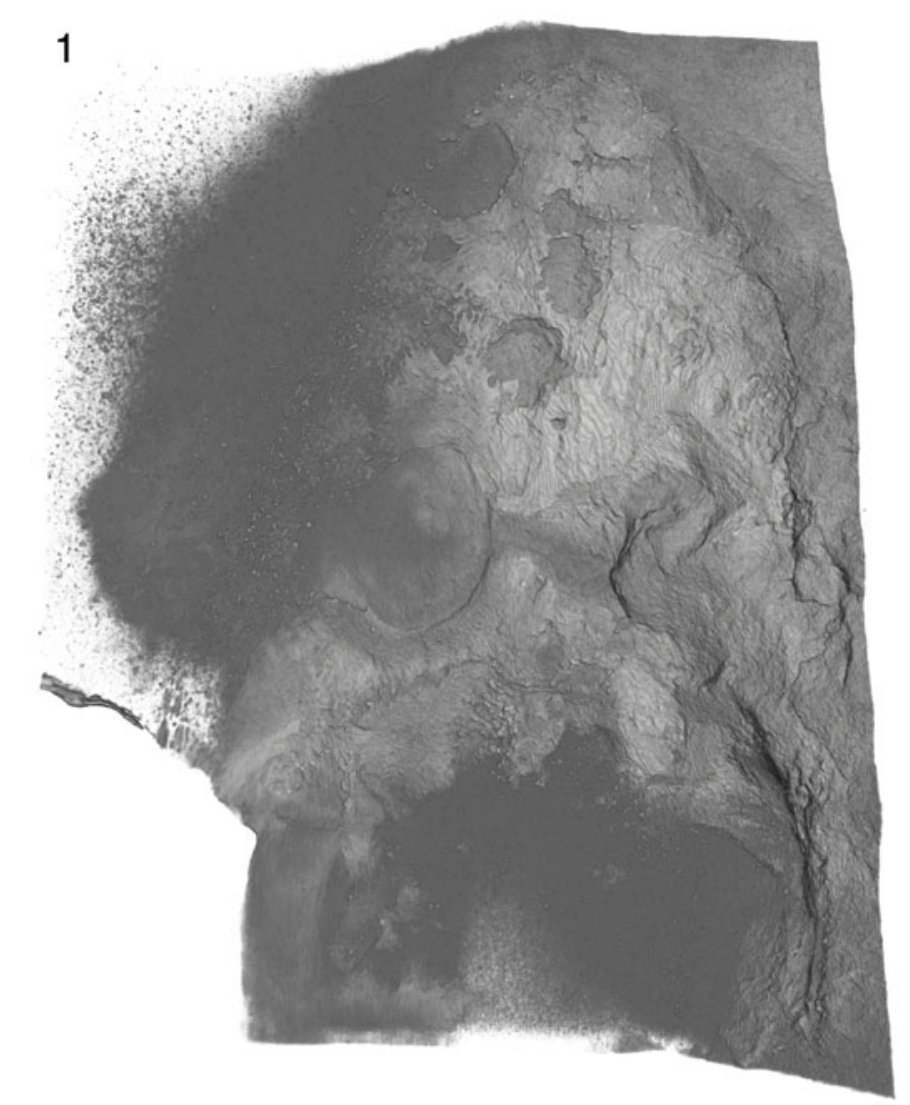

2

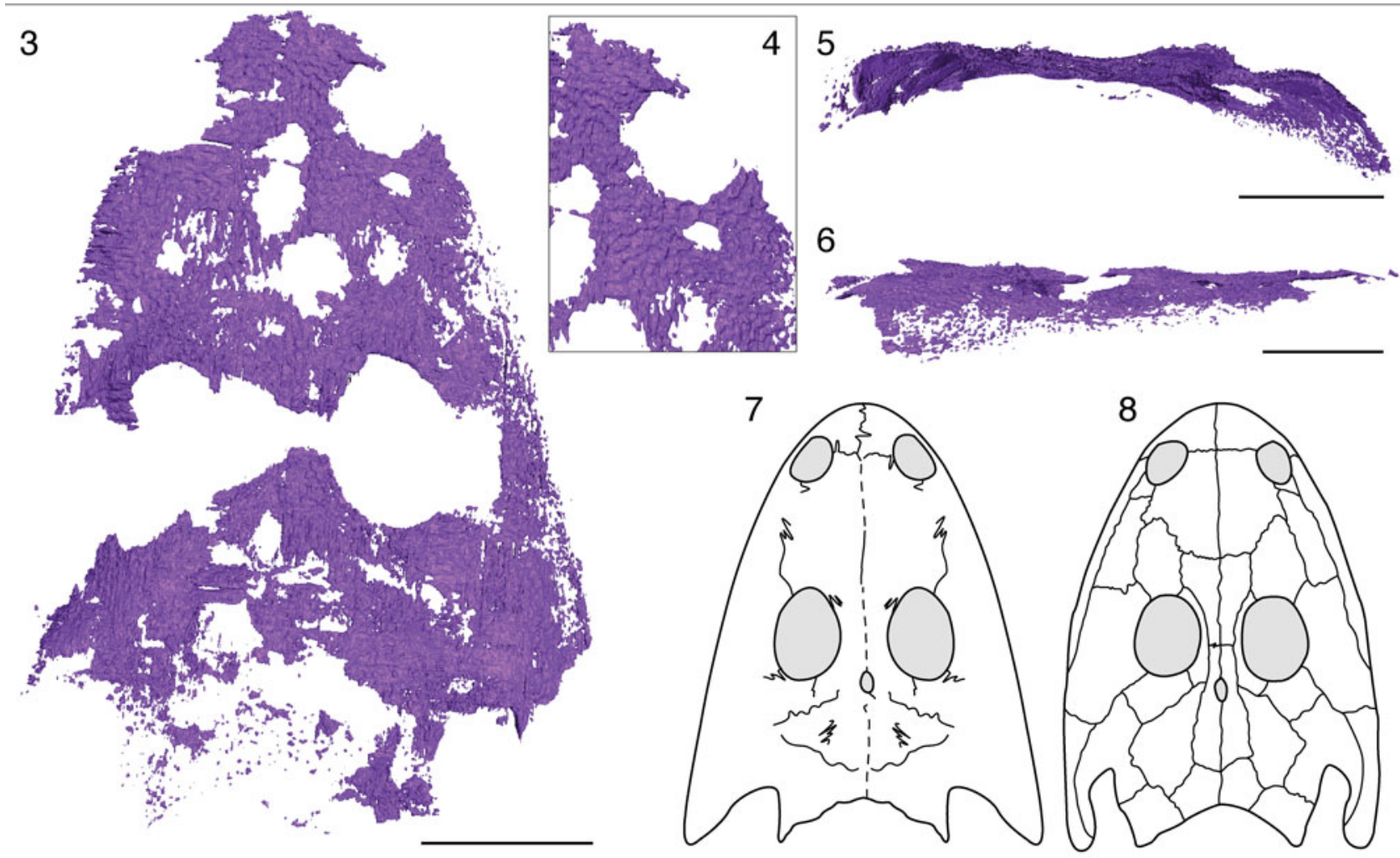

Figure 4. Tomographic visualization of AMNH FARB 9503 ('Cryobatrachus kitchingi'). (1) Volume rendering of the block with brightness and contrast settings that were used during segmentation; (2) isolated skull roof in ventral view; note that this is not directly orthogonal to the plane of the roof; (3) isolated skull roof in orthogonal dorsal view; (4) close-up of the right pre-orbital region of the skull in dorsal view, showing the ornamentation; (5) isolated skull roof in posterior view; (6) isolated skull roof in right lateral view; (7) new reconstruction of AMNH FARB 9503 in dorsal view; (8) original reconstruction of AMNH FARB 9503 from Colbert and Cosgriff (1974). Scale bars $=1 \mathrm{~cm}$. 

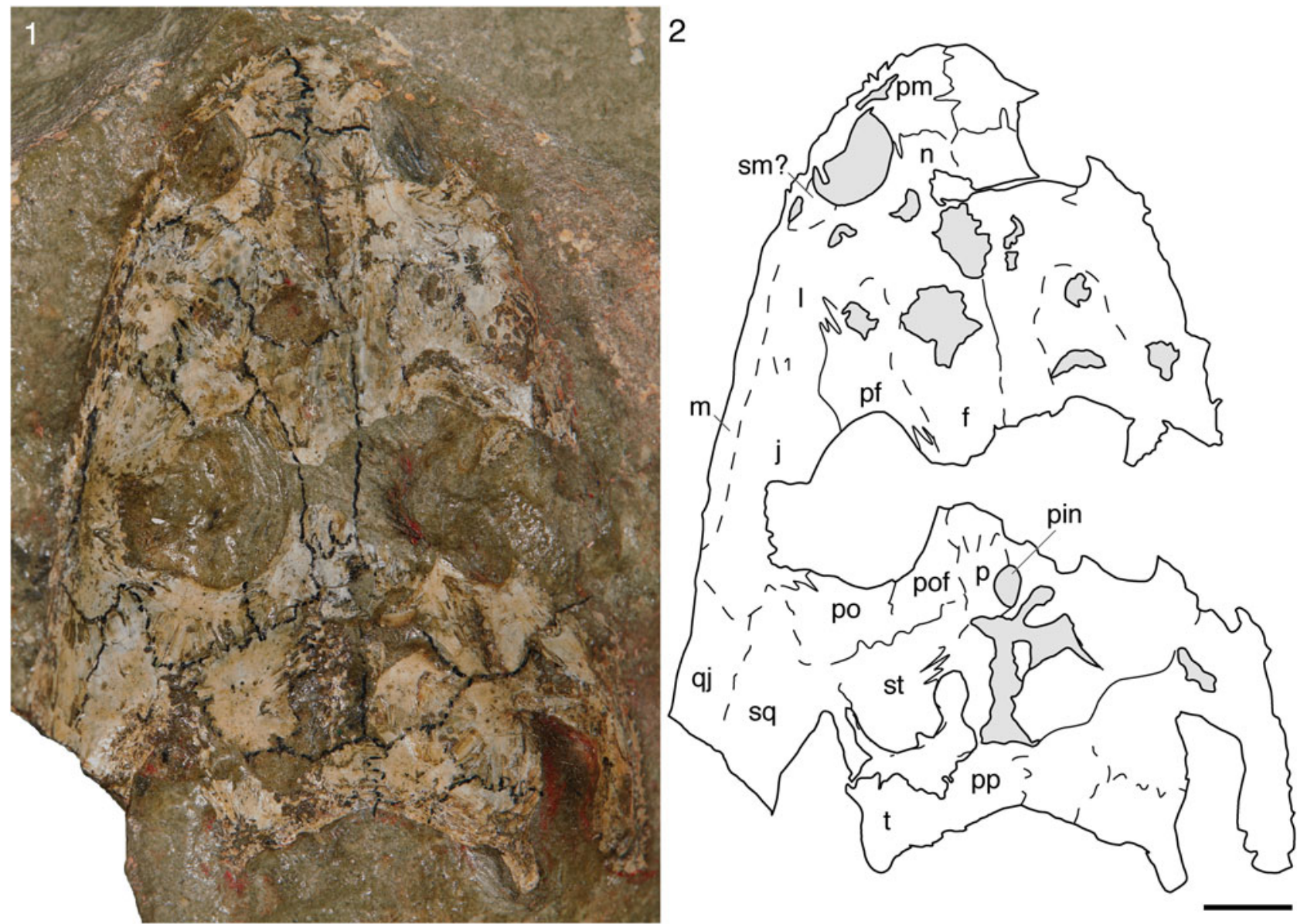

Figure 5. Photograph and new interpretive line drawing of AMNH FARB 9503 ('Cryobatrachus kitchingi'). (1) Close-up photograph of the skull roof; (2) interpretive line drawing. Solid lines represent confidently identified sutures; dashed lines represent marked sutures that could not be verified. Abbreviations: $\mathrm{f}$, frontal; $\mathrm{j}$, jugal; l, lacrimal; m, maxilla; n, nasal; p, parietal; pf, prefrontal; pin, pineal foramen; pm, premaxilla; po, postorbital; pof, postfrontal; pp, postparietal; qj, quadratojugal; sm, septomaxilla; sq, squamosal; st, supratemporal; t, tabular. Scale bar $=5 \mathrm{~mm}$.

Occurrence.-The holotype was collected from the lower member of the Fremouw Formation (Lower Triassic), Kitching Ridge, Shackleton Glacier, Antarctica. The single paratype and referred specimens (not addressed here) are from other lower Fremouw Formation localities: Thrinaxodon Col, Coalsack Bluff, Halfmoon Bluff, Shenk Peak, and Collinson Ridge.

Description.-The use of permanent marker to trace purported sutures greatly complicated our re-examination of the holotype. There are only two published photographs: a low-resolution version published by Kitching et al. (1972, fig. 3D) in a short note on new collections from Antarctica; and the slightly better version published by Colbert and Cosgriff (1974, fig. 14A). As noted above, the specimen clearly lacks the marking in both photographs, neither of which is sufficient to discern any sutures; this is also complicated by the low-contrast white coloration of the fossil. Validating the sutures is further complicated by variation in the markings; some lines are solid, and others are dashed, but Colbert and Cosgriff (1974) presented only solid lines in both their interpretive line drawing and in their reconstruction (reproduced in Fig. 2). It is not clear when the markings were added, or by whom.
Based on historical conventions, the dashed lines probably indicate inferred sutures that were not actually identifiable. This is partially validated by the inability to discern any sutures through the gaps in these dashed lines, although lines drawn over matrix that connect inferred sutures (e.g., the median frontal suture) are consistently solid despite being inherently inferred. Presumably, the solid lines drawn on the fossil represent more confidently identified sutures, but it is not possible to validate these since they would overlie any physical trace of the suture. Only in a few instances does the marking follow a dislodged edge (only in the postorbital region), which can be inferred, but not confidently identified, as a break along the sutural contact. While a misidentified suture could be invalidated by the identification of the correct suture, it is not clear from historical photographs that sutures are (or ever were) discernible on most of the specimen. It is peculiar that most of the left pre-orbital region (Fig. 2.1) was not interpreted by Colbert and Cosgriff (1974) because this region is no more poorly preserved than any other part of the skull, but upon re-examination, sutures are practically indiscernible. Neither does it appear to be a selective illustrative choice because they illustrated some paired sutures on each side (e.g., premaxilla-nasal, lateral margin of the prefrontal). It is not implausible that the majority of sutures 
might simply have been assumed based on the inferred affinities of the specimen that were based on its overall proportions and size; Colbert and Cosgriff (1974, p. 22) termed the sutures as "typical for temnospondyls." Therefore, only removal of the ink (for which permission was not granted due to archival purposes) or tomographic analysis can confidently validate the sutural interpretations. As noted in the Methods, the tomographic analysis was generally insufficient to confidently differentiate breaks, sutures, and sutures exaggerated by breakage (Figs. 3, 4). The description therefore characterizes the state of the specimen with respect to the traced-on sutures, but we make clear distinctions between confidently observed sutures and those that seem more tenuous (Fig. 5).

The specimen is fairly complete, with damage to the circumorbital region on both sides, the right temporal region, and the left circumnarial region (Figs. 3-5). The ventral surface is generally smooth (i.e., non-weathered), although in a few places, particularly on the posterior skull table, the underside of the dermal ornamentation is visible, indicating that these regions were weathered through (Fig. 5.1). Distortion of the skull is obvious from the discrepancy in width between the two halves of the skull (the left side is narrower), as remarked upon by Hewison (2007), and which is also apparent from Colbert and Cosgriff's (1974) original figures (Fig. 2). Rendering the skull in three dimensions makes it clear that the left side is compressed, rather than the right side having been flattened, as evinced by the distortion of the left orbit (Fig. 4.5). A broken fragment along the anterolateral margin projects ventrally as well.

Undistorted, the skull would have been flat with shallowly sloping lateral margins (Fig. 4.6). The skull is long and fairly narrow, broadening very gradually and with nearly straightsided lateral margins. The orbits are large ovals, with the long axis oriented longitudinally. The interorbital distance can be estimated to be slightly less than the maximum width of the orbit. The nares are smaller ovals oriented obliquely anteromedially. The preorbital region is slightly longer than the postorbital region, and there is a distinct prenarial region (i.e., the external nares are not at the edge of the snout). The occipital margin is sharply concave in ventral view. The left otic notch is deeply incised, extending to the level of the anterior margin of the postparietal, which is quite deep for a temnospondyl. Hewison (2007) surmised that this could be taphonomic damage that exaggerated the depth, which would explain the sharply tapering border. However, the anterior margins of the notch are relatively smooth, indicating that there was not much, if any, damage in this region. The ventral exposure of the notch also may influence the perception, but this region was very poorly resolved in the tomographic analysis and cannot be visualized in dorsal view.

Ornamentation, revealed through the tomographic analysis (Fig. 4.4), indicates the stereotypical pits that characterize most temnospondyls. It is not possible to fully assess variation in ornamentation across the skull, but it appears even throughout the preorbital region, without zones of intensive growth or zones lacking ornamentation. There is no evidence for a more apomorphic pattern (e.g., the 'spider web' pattern of rhytidosteids), distinctive pustules or cornules like those in plagiosaurids or Micropholis stowi, or larger topographic features of the ornamentation such as depressions or nodules. There is also no evidence for lateral line grooves on at least the snout region (typically found in facultatively or obligately aquatic taxa), and the other regions where grooves may be preserved (lateral margin of skull, postorbital region) could not be sufficiently resolved in the tomographic analysis.

Colbert and Cosgriff's (1974) characterization of the sutures as "typical" for temnospondyls indeed aligns with the marked sutures (Figs. 2, 5). There is no intertemporal, a plesiomorphic feature whose absence can be validated under the assumption that breaks in the postorbital region occurred along sutural contacts. Colbert and Cosgriff (1974) figured a large lacrimal, which is confidently absent only in brachyopids, chigutisaurids, and most rhytidosteids among stereospondyls (e.g., Warren and Marsicano, 2000; Dias-da-Silva and Marsicano, 2011; Schoch and Milner, 2014), but this could not be validated here. They did not figure a lateral exposure of the palatine (LEP), which is a feature restricted to some dvinosaurs (e.g., Foreman, 1990; Sequeira, 1998; Englehorn et al., 2008; Schoch and Voigt, 2019), dissorophoids (e.g., Bolt, 1974), and the controversial stereospondyls Chinlestegophis Pardo, Small, and Huttenlocker, 2017, and Rileymillerus Bolt and Chatterjee, 2000. The LEP replaces the lacrimal entirely in some dvinosaurs (e.g., Shishkin, 1973; Warren, 1998a), a condition purported to also be found in Chinlestegophis and Rileymillerus (Pardo et al., 2017), although this has been disputed (Schoch, 2008a; Schoch et al., 2020). No broken surface is present on the ventral surface, which would be expected for a palatine exposed both laterally and ventrally.

The premaxillae are sizeable, forming the large prenarial region, and share a transverse suture with the nasals around the medial narial margin. What appears to be an internarial fontanelle in the tomographic reconstruction (Fig. 4) is an artifact of the low contrast; there is no opening on the specimen itself (Fig. 5). Purportedly, there is a septomaxilla at the posterior end of the right naris that separates the lacrimal (which cannot be positively identified) from the opening (Fig. 2), but sutures in this region could not be verified. A suture that is newly identified posterior to the left naris in the same position could alternatively be a nasal-maxillary suture, irrespective of the presence or absence of a septomaxilla. The lacrimal probably was present given the lack of evidence for a LEP, but it can only be identified by position, and the only preserved edge would be the posteromedial suture with the prefrontal. Because some taxa lack both a LEP and a lacrimal (e.g., most brachyopids, chigutisaurids, most rhytidosteids; Warren and Marsicano, 2000; Dias-da-Silva and Marsicano, 2011), the absence of an LEP is insufficient to be assured of the presence of a lacrimal. With that said, AMNH FARB 9503 clearly does not have a brachycephalic shape like the brachyopoids, and the overwhelming majority of temnospondyls lack a LEP and retain a lacrimal. Sutures of the maxilla, the jugal, and the quadratojugal cannot be validated, but their original interpretations were typical for stereospondyls (e.g., jugal terminating at the level of the anterior orbital margin). The prefrontal is defined laterally and posteromedially, and it contributes to the anterior orbital margin. Contrary to Colbert and Cosgriff (1974), we place its posterior margin along the anteromedial orbital margin, and it is not clear whether this contact is with the frontal (implying separation from the postfrontal) or with the postfrontal (as Colbert and Cosgriff illustrated; Fig. 2). Neither side preserves a complete dorsal mid-length of the orbital margin (Figs. 4, 5). 
Midline elements are poorly defined posterior to the premaxillae (Fig. 5). The nasals and frontals are only tentatively identified based on their position. The parietals are mostly lost or weathered and are defined only by the oval pineal foramen. This foramen appears to be situated relatively far anteriorly within the parietals, but the anterior extent of the parietals is unknown. As interpreted by Colbert and Cosgriff (1974), the parietals terminate just anterior to the foramen (Fig. 2). The postparietals are square elements that contribute to the occipital margin.

The elements of the posterior skull table are also "typical" for temnospondyls, and the sutures of the right side are more confidently resolved here, largely because of breaks along their inferred contacts (Fig. 5). The postfrontal extends from an indeterminate point anteriorly to frame the orbit, meeting the postorbital along the posteromedial orbital margin. Based on our interpretation of the prefrontal's posterior margin, the postfrontal would not be as extensive anteriorly as Colbert and Cosgriff (1974) illustrated (Fig. 2). The postorbital is a square element with a squared-off posterior edge, sutured to the squamosal and to the supratemporal. The squamosal has an anterior process that meets the jugal along the posterolateral orbital margin. It also contributes to the otic notch with the tabular, although it is unknown whether the elements contacted or were interrupted by the supratemporal. As previously noted, it is not clear whether the otic notches are artificially deeply incised into the squamosal. The supratemporal is a nondescript square element, at least as preserved. The tabular has a distinct tabular horn that projects posterolaterally and only slightly ventrally. It has a rounded tip and is offset from the main rectangular body of the tabular. Little can be said about the quadratojugal other than that it forms the posterolateral corner of the skull; its contribution to the otic notch is unknown. The posteriormost margin of the quadratojugal, which appears to be undamaged, is posterior to the level of the postparietals at the midline, but anterior to the level of the posterior terminus of the tabular horns. No elements of the palate, occiput, neurocranium, or postcranial skeleton are preserved.

Remarks.- 'Cryobatrachus kitchingi' is maintained as a nomen dubium (Schoch and Milner, 2000) because AMNH FARB 9503 preserves no diagnostic features of its own (all of those purported by Colbert and Cosgriff, 1974, cannot be verified) and cannot even be confidently referred to a particular clade within Temnospondyli. Although we have only examined the holotype first-hand, none of the referred material (AMNH FARB 9331，9332，9339-9345，9347，9348，9382-9388; 24224 [formerly WSUVP 1012]; or WSUVP 1099 [which is not at the AMNH and appears to have been lost; note, however, that AMNH FARB 24229 was previously WSUVP 1098 and is a sculptured fragment as reported for WSUVP 1099]) or the paratype (AMNH FARB 9556) of 'Cryobatrachus kitchingi' preserves diagnostic features of the Lydekkerinidae. This is also true of material referred only to 'Cryobatrachus sp.' (AMNH FARB 9537, 9540, 9541). All of this material was referred to the taxon simply on the basis of either shared small size or by similar ornamentation (Colbert and Cosgriff, 1974; Cosgriff and Hammer, 1984), which, as discussed in the Materials section, is not diagnostic to
Lydekkerinidae, let alone to a particular taxon. Because Schoch and Milner (2000, p. 165) did not specify which of this material was "clearly genuine lydekkerinid material," and the composition of Lydekkerinidae is uncertain (e.g., Jeannot et al., 2006; Hewison, 2007; Eltink et al., 2019), we consider the non-holotype material of 'Cryobatrachus kitchingi' to be Temnospondyli indet. at present, and this suite of material should not be cited as unequivocal evidence of the presence of lydekkerinids in Antarctica.

Order Temnospondyli Zittel, 1888

Suborder Stereospondyli Zittel, 1888

cf. Lydekkerinidae Watson, 1919 sensu Jeannot et al., 2006

Figure 6

Description.-FMNH PR 5020 is a partial skull, exposed dorsally, with an overlying vertebral column of Prolacerta Parrington, 1935 (Fig. 6.1). The skull is cleanly broken at an oblique angle extending from the mid-length of the left orbit to a position just anterior to the right orbit. As preserved, the skull is mostly flat with shallowly sloping lateral margins. Of note is the presence of a distinct trough in the interorbital region, which is in part framed by a distinct orbital rim along the dorsal edge. The snout is parabolic and forms a smoothly confluent lateral margin that is essentially straight. The maximum length of the specimen is $7.3 \mathrm{~cm}$, with a preorbital length of $4.1 \mathrm{~cm}$. Measured from the posteriormost preserved point, it is slightly wider than it is long $(\sim 8.0 \mathrm{~cm}$ wide), but it can be reasonably inferred that the skull would be slightly longer than wide when complete. The cranial ornamentation is evenly developed throughout and consists of subcircular pitting without any grooves or ridges. The intersections between pits often comprise distinct nodes or ridges, but the ornamentation is neither pustular nor tubercular. Lateral line grooves are clearly absent on the snout, but a short supraorbital canal is present on each side, formed by numerous very poorly defined pits and extending along the presumed maxilla. The left canal appears to turn medially; usually this is termed a 'step-like flexure.' Portions of the infraorbital canals are present just anterior to the interorbital region, although their extents are unclear due to damage and overlying elements.

Unfortunately, despite the relative fidelity of preservation, very few sutures are apparent other than the medial margin of the left maxilla, even in areas that are well exposed and where suture position is highly predictable (e.g., the midline suture; Fig. 6.4, 6.5). Cracks seem more likely to be random than to follow sutural contours (e.g., a crack lateral to the left orbit that is confluent with a crack through an overlying vertebra that does not conform to a predicted suture). The midline is only defined at the tip of the snout with the posteromedial margin of the premaxilla identified as a transverse line. As preserved, the left naris is nearly as long as the orbit $(0.9 \mathrm{~cm})$, but the posterior margin is clearly damaged. The right naris' posterior margin is not identified, but bone extends anterior to the level of the left naris' posterior margin. The left orbit is sufficiently complete to note that it is relatively small for the estimated skull size and that the long axis was oriented anteromedially. The interorbital distance is impossible to estimate, but it appears relatively narrow, unlike that in rhytidosteids, for example. 


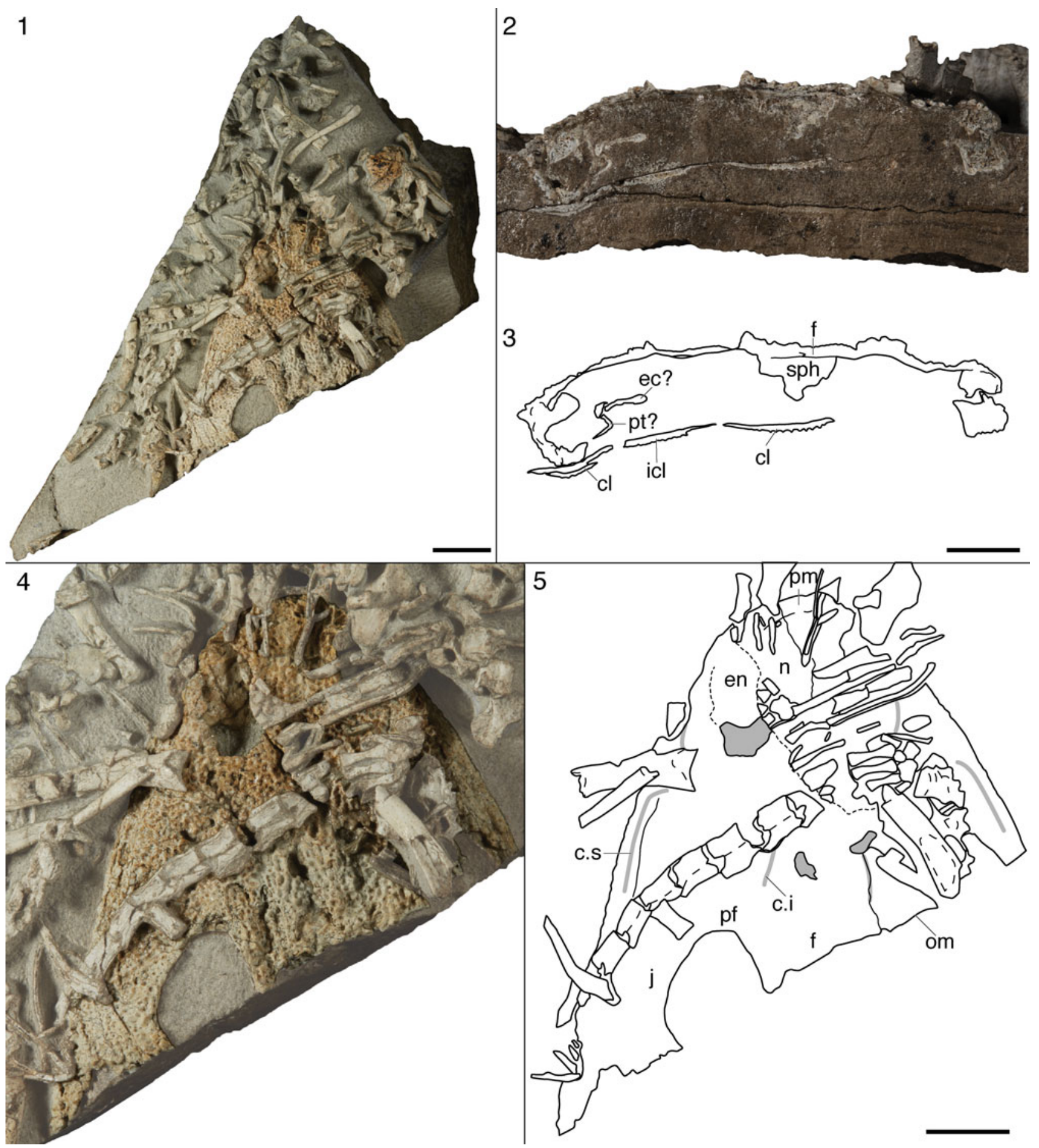

Figure 6. Photographs and interpretive line drawings of FMNH PR 5020 (cf. Lydekkerinidae indet.). (1) Photograph of the entire encapsulating block; (2) photograph of the broken oblique cross-section; note that the photograph is taken head-on relative to the exposed surface; (3) interpretive line drawing of the same; (4) photograph of the skull in dorsal view; (5) interpretive line drawing of the same. Abbreviations: c.i, infraorbital canal; c.s, supraorbital canal; cl, clavicle; ec, ectopterygoid; en, external naris; f, frontal; icl, interclavicle; j, jugal; n, nasal; om, orbital margin; pf, prefrontal; pm, premaxilla; pt, pterygoid; sph, sphenethmoid. Scale bars $=1 \mathrm{~cm}$.

The broken cross-section reveals the presence of both lower jaws in articulation, the left side of the palate, and ornamented bones oriented upside-down relative to the skull (Fig. 6.2, 6.3). The latter are most likely portions of the dermal pectoral girdle, although a clavicle versus interclavicle distinction cannot be unequivocally made. Three distinct elements with ventrally facing ornamentation are present, so the most parsimonious interpretation is that the interclavicle is in the middle, more or less below the left orbit, with the left clavicle below the left lower jaw and the right clavicle below the midline. A subtriangular bone with concave ventrolateral margins is located below the interorbital region of the skull roof and is interpreted 
as the sphenethmoid. The palatal elements probably comprise the palatine ramus of the pterygoid and the ectopterygoid based on the longitudinal position (ventral to the posterior half of the orbit). There is no evidence for preservation of either the cultriform process (unless it is indistinguishably fused to the sphenethmoid) or the right side of the palate, suggesting that a large portion of the palate may have been dislodged.

Remarks. - We follow the family-level concept of Jeannot et al. (2006), rather than the more recent amended version of Hewison (2007), because the former is more inclusive and in line with current workers' concept of Lydekkerinidae (e.g., Dias-da-Silva and Hewison, 2013). The composition of the family is considered here to include Chomatobatrachus Cosgriff, 1974, Deltacephalus Swinton, 1956, Eolydekkerina Shishkin, Rubidge, and Kitching, 1996, Luzocephalus Shishkin, 1980, and Lydekkerina (as with Dias-da-Silva and Hewison, 2013), rather than excluding Deltacephalus as proposed by Jeannot et al. (2006) or excluding Chomatobatrachus and Luzocephalus as proposed by Hewison (2007). The concept is explicitly stated here only to be clear about what is implied with the terms 'Lydekkerinidae' and 'lydekkerinid' in the discussion and is not a formal opinion on the composition of the clade. The discussion also follows the concept of Lydekkerina huxleyi of Jeannot et al. (2006), in which 'Broomulus dutoiti' Broom, 1930, and 'Limnoiketes paludinatans' Parrington, 1948, are considered junior synonyms of L. huxleyi, rather than Hewison's (2007) framework in which both are considered distinct taxa.

\section{Discussion}

Phylogenetic analysis. - The analysis with the OTU of AMNH FARB 9503 based on Colbert and Cosgriff (1974) recovered nine MPTs with a length of 1,081 steps $(\mathrm{CI}=0.340 ; \mathrm{RI}=0.685$; $\mathrm{HI}=0.664$; Fig. 7.1). The strict consensus topology is poorly resolved with respect to Stereospondylomorpha, with many major clades, including Stereospondyli, either not recovered at all or not recovered with all nominal members. AMNH FARB 9503 clusters with lapillopsids in this analysis; this clade is one branch of a large stereospondylomorph polytomy. Examination of individual MPTs revealed that there are three different positions of this clade: five MPTs $(1-2,5-7)$ recover this clade at the base of Stereospondylomorpha; three MPTs recover this clade at the base of Stereospondyli $(3-4,8)$; and one MPT (9) recovers this clade as highly nested within Stereospondyli as the sister group to Chinlestegophis jenkinsi + Rileymillerus cosgriffi, which is the collective sister group of Brachyopoidea. Note that these three positions do not correspond precisely to the three different islands identified in the search (MPTs 1-6, 7-8, and 9). Bremer and bootstrap support are low for relevant nodes (e.g., a Stereospondylomorpha that includes AMNH FARB 9503; clustering of this specimen with lapillopsids).

The analysis with the revised OTU of AMNH FARB 9503 based on this study's findings recovered three MPTs with a length of 1,074 steps $(\mathrm{CI}=0.340, \mathrm{RI}=0.687 ; \mathrm{HI}=0.663$; Fig. 7.2). The strict consensus topology is much more resolved and is largely congruent with that recovered by previous versions of the matrix. Virtually all major clades were recovered, although Capitosauria forms a grade (as with Pardo et al.,
2017), and the rhytidosteids do not form a clade (as in Schoch, 2013, and Pardo et al., 2017). AMNH FARB 9503 forms a polytomy with the two lapillopsids, with the rhytidosteid Nanolania anatopretia as the sister taxon to this clade. In one MPT, AMNH FARB 9503 and Rotaurisaurus contundo are sister taxa. The lapillopsids + AMNH FARB 9503 are collectively the sister group of Chinlestegophis jenkinsi + Rileymillerus cosgriffi, and together are the sister group of Brachyopoidea. Bremer and bootstrap support are relatively unchanged compared to the previous analysis.

The analysis with FMNH PR 5020 recovered five MPTs with a length of 1,073 steps $(\mathrm{CI}=0.340, \mathrm{RI}=0.687 ; \mathrm{HI}=$ 0.663 ; Fig. 8). The strict consensus topology is nearly identical to that of the previous analysis, with Nanolania anatopretia clustering with lapillopsids, and this clade clusters with Chinlestegophis jenkinsi + Rileymillerus cosgriffi and brachyopoids. FMNH PR 5020 is recovered in a polytomy at the base of Stereospondyli, with branches for the rhinesuchids Broomistega putterilli and Uranocentrodon senekalensis (Van Hoepen, 1911) and one branch for all other stereospondyls (Superstes of Eltink et al., 2019). Examination of the individual MPTs reveals three positions for FMNH PR 5020: nesting with rhinesuchids to form a clade (1-2,5); diverging after a monophyletic Rhinesuchidae (3); and in a polytomy with a monophyletic Rhinesuchidae and Superstes (4). Bremer and bootstrap support are low for most clades. Compared to the analyses with AMNH FARB 9503, support for Lapillopsidae has increased, while support for Lydekkerinidae has decreased, and Rhinesuchidae was not recovered as a clade (although it was recovered in $88 \%$ of bootstrap replicates).

We opted to first conduct the analyses without any ordered characters to mirror previous versions of this matrix, but if characters that can be reasonably inferred to occur along a morphocline are ordered, the results are not substantially different. The analyses of the revised OTU of AMNH FARB 9503 and the OTU of FMNH PR 5020 recovered the same number of MPTs and the same strict consensus topology. The analysis of the Colbert and Cosgriff (1974) OTU of AMNH FARB 9503 recovered a single MPT (compared to nine MPTs without ordering), but the position of this specimen (sister to lapillopsids) is unchanged, and the relationships of other taxa are as with the strict consensus from the analyses using the revised OTU for this specimen.

We emphasize caution in literal interpretation of the results of any of these analyses, in particular those that sample AMNH FARB 9503, which clustered with lapillopsids (Figs. 7, 8). For one, there remains the question of whether lapillopsids nest within Lydekkerinidae (Eltink et al., 2019), a result that has not been recovered previously in temnospondyl-wide matrices (e.g., McHugh, 2012; Schoch, 2013, and derivates), including this study. If so, then clustering of AMNH FARB 9503 with lapillopsids would not necessarily indicate non-lydekkerinid affinities. Lapillopsids have never been recovered in the position found here-highly nested as part of a sister clade to Brachyopoidea (Figs. 7, 8) - but neither have they been previously sampled with so many small-bodied taxa, and Lapillopsis nana is usually the only representative. The only reasonable conclusion is that the longstanding uncertainty in the position of lapillopsids continues to persist (e.g., Warren and 
1

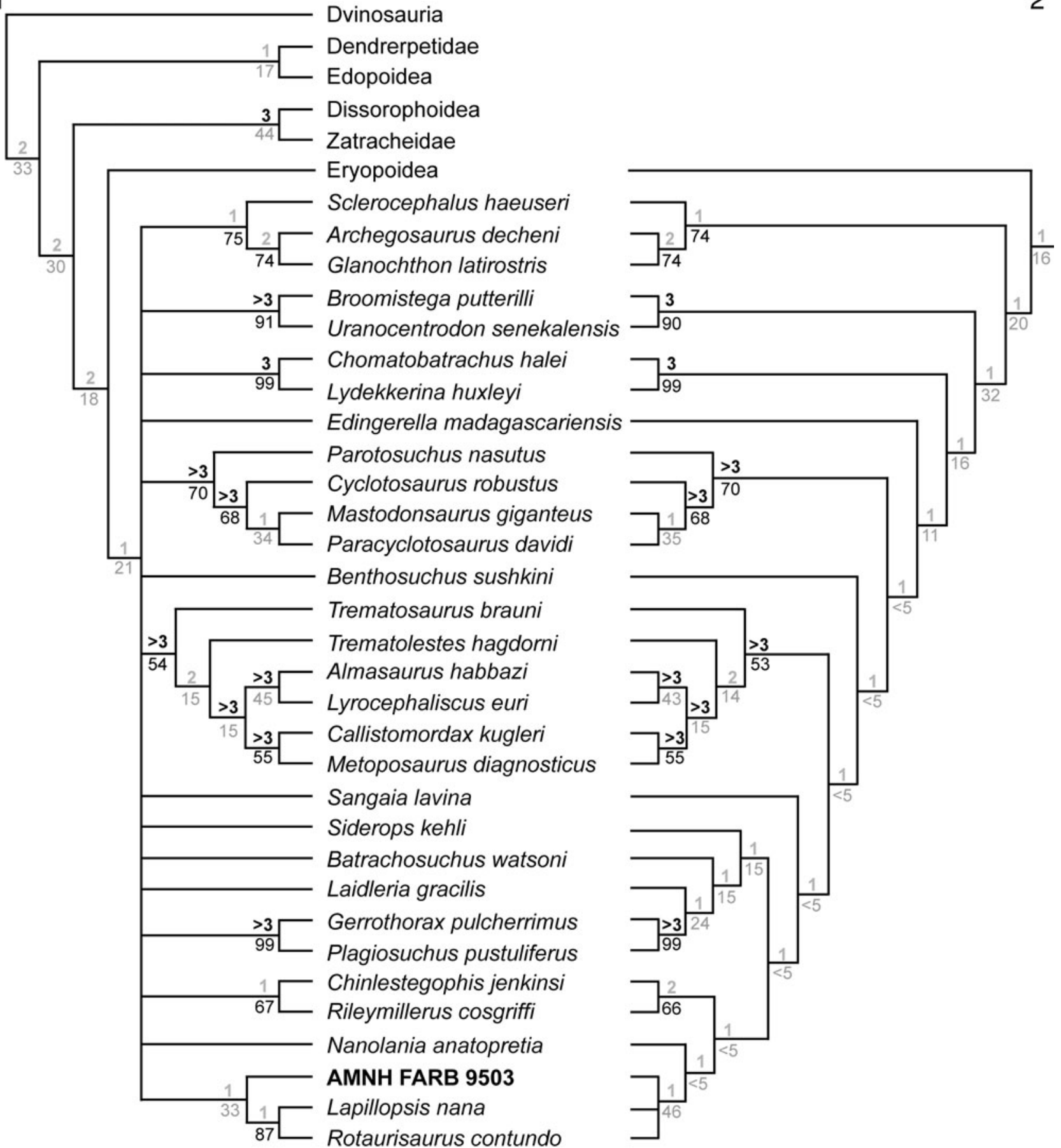

Figure 7. Strict consensus topologies from the phylogenetic analysis of AMNH FARB 9503. (1) Resultant topology from the analysis using the OTU derived from Colbert and Cosgriff's (1974) interpretations; (2) resultant topology from the analysis using the OTU derived from this study's reevaluation of the specimen. Nonstereospondyl clades are visually consolidated; due to space constraints, these are not depicted in part 2, but the relationships are unchanged. Bold numbers above lines are Bremer decay indices; non-bold numbers below lines are bootstrap values. Support values are grayed out when they do not meet standard thresholds of strong support (Bremer $>2$; bootstrap $\geq 50 \%$ ).

Hutchinson, 1990a; Yates, 1999; Yates and Warren, 2000; Ruta et al., 2007; McHugh, 2012; Schoch, 2013; Pardo et al., 2017). AMNH FARB 9503 does not actually share any apomorphies with lapillopsids (sensu Yates and Sengupta, 2002). Most of the skeletal regions where lapillopsid synapomorphies occur are not even preserved in AMNH FARB 9503 (e.g., palate, mandible). We interpret the recovered position of this specimen and that of lapillopsids as support for our hypothesis that small body size (whether or not due to immaturity) is a homoplastic feature that can lead to clustering of unrelated taxa that are united by ontogenetically variable qualitative features.

Additional support for this hypothesis is found in the position of the rhytidosteid Nanolania anatopretia, which does not cluster with the other sampled rhytidosteids (Laidleria gracilis, 


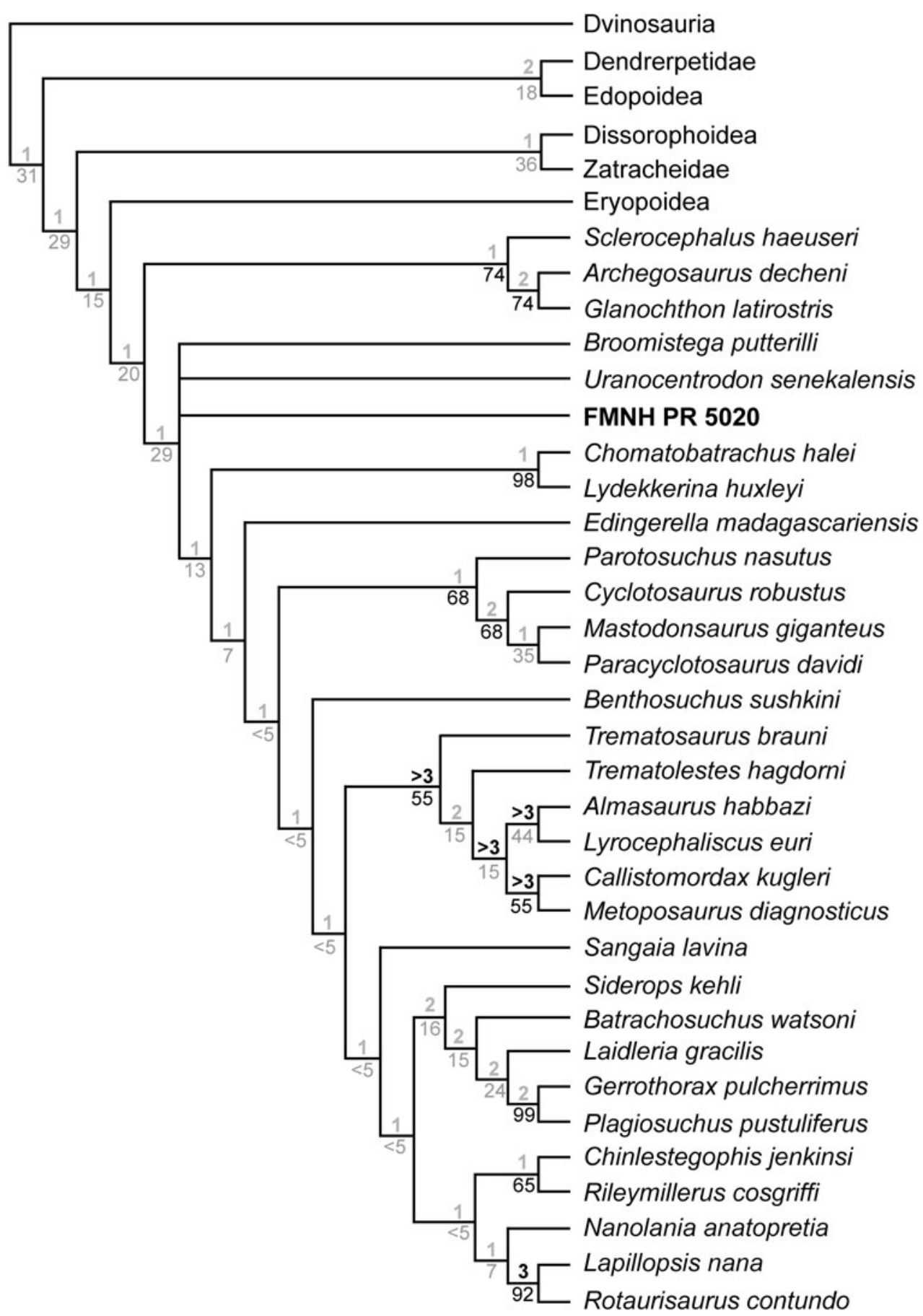

Figure 8. Strict consensus topology from the phylogenetic analysis of FMNH PR 5020. Non-stereospondyl clades are visually consolidated. Bold numbers above lines are Bremer decay indices; non-bold numbers below lines are bootstrap values. Support values are grayed out when they do not meet standard thresholds of strong support (Bremer $>2$; bootstrap $\geq 50 \%)$.

Sangaia lavina [Dias-da-Silva, Marsicano, and Schultz, 2006]) but rather with lapillopsids (Fig. 7) or with Chinlestegophis jenkinsi + Rileymillerus cosgriffi (Fig. 8). Nanolania anatopretia is the smallest rhytidosteid, and therefore may be attracted to other similarly sized taxa, given both the size and morphological disparity from other rhytidosteids (e.g., Dias-da-Silva and Marsicano, 2011). The historical recovery of lapillopsids as the sister group to Dissorophoidea in some previous analyses with fewer small-bodied taxa (Schoch, 2013; Pardo et al., 2017) also confers support to our hypothesis. Lapillopsis nana was originally considered to be a micropholid amphibamiform (Warren and Hutchinson, 1990a), but exhibits many stereospondyl features, and therefore morphologically converges on small-bodied dissorophoids only due to shared small size (e.g., Yates, 1999). The shift in position in this analysis may result from the addition of Rotaurisaurus contundo, N. anatopretia, and the specimens of interest in this study, which are all small in size. 
Similar caution should be exercised in interpreting the results of the analysis with FMNH PR 5020. Falling within a polytomy with rhinesuchids and Superstes does not necessarily indicate that it is a rhinesuchid. Its early diverging position may merely reflect the relatively low number of characters for which it can be scored and the generic suite of plesiomorphies that can be identified. In three of the MPTs, FMNH PR 5020 clusters with rhinesuchids, which are the earliest diverging stereospondyls. In one of the other MPTs, it is the earliest diverging stereospondyl, and in the last MPT, it diverges after rhinesuchids but before lydekkerinids. Given our reservations about the phylogenetic results for both specimens, the following sections provide a detailed qualitative anatomical comparison to further evaluate their affinities.

Anatomical interpretations of 'Cryobatrachus kitchingi' based on AMNH FARB 9503.- Re-examination of AMNH FARB 9503 leads to the conclusion that most of the sutures depicted by Colbert and Cosgriff (1974) cannot be validated unless the permanent marker is removed. It is possible that doing so might reveal that most of the sutures still cannot be validated. Most of the sutures may have been tenuous all along based on the prevalence of dashed lines, and we could not identify any traces of sutures in the spaces between these lines. It is certainly possible that most of the original illustrated sutures (Fig. 2) could have been inferred based on either a stereotypical lydekkerinid or stereospondyl configuration (the "typical" configuration). Not all sutures, especially in the postorbital region of the skull, have substantial variation among stereospondyls. For this reason, the sutural interpretations are essentially wholly uninformative for assessing its taxonomy. Two features warrant particular discussion because they have potentially stronger phylogenetic implications.

The first feature is the purported dorsal exposure of the septomaxilla bordering the naris posteriorly, thereby separating the lacrimal from the naris (or separating the prefrontal from the naris in taxa without a lacrimal). Among clades with Mesozoic representatives, this condition is found in some brachyopoids (inclusive of plagiosaurids in this context; Schoch, 2013; Schoch and Milner, 2014), dvinosaurs, lydekkerinids, rhinesuchids, and trematosaurs (e.g., Shishkin and Welman, 1994; Shishkin et al., 1996; Sequeira, 1998, Warren and Marsicano, 1998; Shishkin and Rubidge, 2000; Damiani and Jeannot, 2002; Damiani and Yates, 2003; Dias-da-Silva et al., 2006), and it was one of the more compelling lines of evidence for lydekkerinid affinities of AMNH FARB 9503 (Shishkin et al., 1996). Septomaxillae are rarely preserved in other clades, which suggests that it was a loosely articulated intranarial ossification that was susceptible to taphonomic loss; this can be seen in capitosaurs (e.g., Howie, 1972; Muhkerjee and Sengupta, 1998), metoposaurids (e.g., Chakravorti and Sengupta, 2018), and amphibamiforms (e.g., Schoch and Rubidge, 2005). Both taphonomic and intraspecific variation in the preservation and configuration of the septomaxilla has been documented in Lydekkerina huxleyi by Jeannot et al. (2006, fig. 5) and Hewison (2007, fig. 6). The entire septomaxilla in AMNH FARB 9503 is marked with dashed lines, and we could not identify a suture there, either externally or in the CT data. Posterior to the left naris is a short suture that Colbert and Cosgriff (1974) did not identify; this either could be one margin of the septomaxilla or a short maxilla-nasal contact (either would exclude the lacrimal from the naris). The lacrimal can only be identified tentatively by position because it is not fully defined. Because the septomaxilla is more frequently lost or not dorsally exposed (as in the lydekkerinids Chomatobatrachus Cosgriff, 1974, Deltacephalus Swinton, 1956, and Luzocephalus SäveSöderbergh, 1935), the condition in AMNH FARB 9503 should be regarded as indeterminate.

The second feature is the purported anteriorly extensive postfrontal. If this interpretation is correct, it would singlehandedly re-validate the taxon because it would be autapomorphic among Temnospondyli. Prefrontal-postfrontal contact is plesiomorphic for temnospondyls, and it is found in the vast majority of stereospondyls. Among stereospondyls, capitosaurs are the one exception in which the frontal enters the orbit in a large number of taxa (e.g., Schoch, 2000, 2008b; Schoch and Milner, 2000; Damiani, 2001). This condition is also found in the two lapillopsids (of three total species) for which cranial material is known (Yates, 1999) and in some of the highernested non-stereospondyl stereospondylomorphs (e.g., Gubin, 1991; Golubev, 1995). As far as is known, this condition does not change throughout ontogeny across Temnospondyli (e.g., Bystrow and Efremov, 1940; Welles and Cosgriff, 1965; Warren and Hutchinson, 1988; Yates, 1999; Shishkin and Rubidge, 2000; Steyer, 2003; Schoch and Rubidge, 2005; Witzmann, 2005; Schoch and Witzmann, 2012), with perhaps the exception of the earliest stage of development in the zatracheid Acanthostomatops vorax (Credner, 1883) (Witzmann and Schoch, 2005). Regardless of the arrangement of the circumorbital elements or cranial proportions, the postfrontal almost never extends beyond a point just anterior to the mid-length of the orbit, and it never forms part of the anterior orbital margin as interpreted for ' $C$. kitchingi' by Colbert and Cosgriff (1974; Fig. 2). The only exception to the latter is the Late Triassic Chinlestegophis jenkinsi Pardo, Small, and Huttenlocker, 2017, a putative brachyopoid (or close relative of brachyopoids) with a markedly different cranial anatomy; in this taxon, the apparent loss of a distinct lacrimal has resulted in an anterolateral shift in the position of the prefrontal and the postfrontal. A few branchiosaurids and brachyopids have relatively anteriorly extensive postfrontals that extend well past the orbital mid-length, but the postfrontal does not extend onto the anterior orbital margin (e.g., Schoch and Milner, 2014, figs. 26, 46, for comparisons). There are also some taxa in which the anterior terminus of the postfrontal closely approaches the level of the anterior orbital margin, but in these taxa (e.g., Sclerocephalus haeuseri Goldfuß, 1847, Onchiodon labyrinthicus Geinitz, 1862; Boy, 1988, 1990) the postfrontal does not follow the contour of the orbit anteriorly such that the anterior terminus is well separated from it. Colbert and Cosgriff's (1974) interpretation is predicated on two points: (1) a short oblique suture extending from the anterior orbital margin as the posteromedial edge of the right prefrontal; and (2) an associated oblique suture set at a right angle as the medial edge of the right frontal (Fig. 2). The former appears to be marked by a partial incisure at the orbital margin, but there is clear complex interdigitation posterior to this point (Fig. 5). This position is more "typical" in being around the level of the anteriormost extent of the postfrontal when it meets the prefrontal or with the posteriormost extent of the prefrontal when it 
does not meet the postfrontal. The inferred frontal suture is dashed and cannot be validated. If indeed it were present, it could essentially be an extension of the posteromedial margin of the prefrontal under our interpretation.

Ontogenetic interpretation of AMNH FARB 9503.- In the absence of a robust understanding of the cranial sutures, an interpretation of this specimen's ontogenetic status is provided to facilitate taxonomic interpretations. It is important to note the limitations of such an approach given a paucity of ontogenetic series for most taxa, widespread size variation within Temnospondyli, and heterochrony between and within clades (e.g., Steyer, 1996, 2000; Boy and Sues, 2000; Schoch, 2009, 2010, 2014; Witzmann et al., 2009; Pérez-Ben et al., 2019). Consequently, very few features have been demonstrated to be applicable or useful to even the majority of temnospondyl families because most conserved patterns are gradational features, such as elongation of the snout, negative allometry of the orbits, and narrowing of the postparietals (e.g., Witzmann et al., 2009; Pérez-Ben et al., 2019). These conundrums lie at the root of the uncertainty regarding the taxonomic status of AMNH FARB 9503, which encapsulates the historic difficulties associated with identifying smallbodied individuals, whether as juveniles of large-bodied taxa or as adults of small-bodied taxa.

A few features hint at the relative immaturity of $\mathrm{AMNH}$ FARB 9503. The first is the size of the orbits, which scale with negative allometry in most temnospondyls (e.g., Bystrow and Efremov, 1940; Welles and Cosgriff, 1965; Boy, 1988, 1989, 1990, 1993; Warren and Schroeder, 1995; Boy and Sues, 2000; Steyer, 2003; Witzmann and Pfretzschner, 2003; Schoch and Rubidge, 2005; Witzmann, 2005; Witzmann and Schoch, 2005; Witzmann and Scholtz, 2007; Witzmann et al., 2009; Pérez-Ben et al., 2019; Schoch, 2019), as in vertebrates generally. AMNH FARB 9503 has relatively large orbits, a feature that also characterizes miniaturized taxa, such as amphibamiform dissorophoids and lapillopsids (Table 1). However, those taxa tend to have substantially larger orbits than AMNH FARB 9503 or similarly sized juveniles of large-bodied taxa (e.g., Witzmann et al., 2009). The relative orbital size observed in this specimen is more comparable to that seen in the earlier stages of development for the majority of non-miniaturized temnospondyls (e.g., Warren and Schroeder, 1995; Steyer, 2003).
Orbit position also tends to shift posteriorly over ontogeny in stereospondyls such that the orbits are prominently in the posterior half of the skull (e.g., capitosaurs, rhinesuchids, trematosaurs), although this is not the case for short-snouted taxa such as brachyopoids or some other clades like lydekkerinids.

The position of the pineal foramen is another frequently mentioned ontogenetic feature (e.g., Bystrow and Efremov, 1940; Welles and Cosgriff, 1965; Warren and Hutchinson, 1988; Hunt, 1993; Schoch, 1995; Boy and Sues, 2000). The opening is thought to shift posteriorly throughout ontogeny, although this requires at least two data points to determine a taxon-specific reference landmark. In capitosaurs, the level of the posterior orbital margin is sometimes used (e.g., Welles and Cosgriff, 1965), but this landmark is less reliable for most other clades in which the foramen is always well posterior to the orbit. However, the paucity of taxa in which the pineal foramen is in line with, or even anterior to, the posterior orbital margin suggests that when either of these conditions occur, it is fairly informative. The foramen of AMNH FARB 9503 is in line with the posterior orbital margin, the "juvenile" condition in capitosaurs. This condition is also found in juveniles of the early diverging trematosaur Benthosuchus sushkini (Efremov, 1929) (Bystrow and Efremov, 1940), but not in adults or in specimens of other trematosaurs (e.g., Säve-Söderbergh, 1935; Dutuit, 1976; Getmanov, 1989; Steyer, 2003; Schoch, 2008a, 2019) or in lydekkerinids of any size (e.g., Cosgriff, 1974; Shishkin, 1980; Hewison, 1996, 2007; Shishkin et al., 1996; Jeannot et al., 2006). A similar ontogenetic shift from the level of the posterior orbital margin is noted in the Permian stereospondylomorph Sclerocephalus haeuseri (Boy, 1988; Schoch and Witzmann, 2009a) and the Permian zatracheid Acanthostomatops vorax (Witzmann and Schoch, 2005), and it might be a hallmark of early ontogeny in other taxa. Only three temnospondyl clades commonly have this condition in presumed "adults": amphibamiforms, lapillopsids, and plagiosaurids (e.g., Yates, 1999; Schoch and Milner, 2000, 2014; Warren and Marsicano, 2000). The first two are miniaturized clades, and the third is a brachycephalic clade.

A final feature is the preservation of the specimen. The skull roof is sheared off at the level of the tooth row, essentially symmetrically on each side, and without any remnants of palatal, occipital, or neurocranial elements. The lateral margins of the external nares also have been lost, indicating complete

Table 1. Comparative measurements for small-bodied Early Triassic temnospondyls. References refer to specific figures rather than specimens because all measurements were taken from published figures. Abbreviations: Io, minimum interorbital width; OL, maximum orbit length, measured along the longest axis; Po, postorbital length; Pr, preorbital length; SL, skull length measured along the midline; SW, maximum skull width. Asterisk indicates that the figure is a reconstruction.

\begin{tabular}{|c|c|c|c|c|c|c|}
\hline Taxon & $\mathrm{SL}(\mathrm{cm})$ & SL:SW & OL:SL & Pr:Po & Io:SL & Reference \\
\hline AMNH FARB 9503 & 4.34 & $?$ & 0.23 & 1.529 & 0.147 & This study (Fig. 5.2) \\
\hline Nanolania anatopretia & 1.77 & 0.99 & 0.27 & 1.01 & 0.36 & Yates $(2000$, fig. $4 \mathrm{~A}) *$ \\
\hline Lapillopsis nana & 1.9 & 1.15 & 0.31 & 1.25 & 0.152 & Yates $(1999$, fig. 5A)* \\
\hline Rotaurisaurus contundo & 4.15 & 1.25 & 0.23 & 1.44 & 0.137 & Yates $(1999$, fig. $15 \mathrm{~A}) *$ \\
\hline Micropholis stowi (Karoo - broad) & 3.5 & 1.07 & 0.31 & 0.72 & 0.28 & Schoch and Rubidge (2005, fig. 2C)* \\
\hline Micropholis stowi (Karoo - slender) & 4.2 & 1.19 & 0.34 & 1.07 & 0.28 & Schoch and Rubidge (2005, fig. 2A)* \\
\hline Micropholis stowi (Fremouw) & 3.3 & 0.92 & 0.30 & 0.96 & 0.265 & Gee and Sidor (2021, fig. 2B) \\
\hline Lydekkerina huxleyi & 5.8 & 1.00 & 0.24 & 1.14 & 0.186 & Jeannot et al. (2006, fig. 2A) \\
\hline Broomistega putterilli & 5.3 & 1.20 & 0.24 & 1.53 & 0.145 & Shishkin and Rubidge (2000, fig. 3A) \\
\hline Benthosuchus sushkini & 2.75 & 1.09 & 0.26 & 1.68 & 0.17 & Bystrow and Efremov (1940, fig. 56) \\
\hline Watsonisuchus aliciae & 3.9 & 1.02 & 0.26 & 1.45 & 0.138 & Warren and Hutchinson $(1988$, fig. 4A)* \\
\hline 'Parotosaurus wadei' & 6.6 & 1.12 & 0.13 & 1.98 & 0.13 & Damiani and Warren (1997, fig. 1) \\
\hline Edingerella madagascariensis & 4.6 & 1.00 & 0.22 & 1.47 & 0.156 & Steyer $(2003$, fig. $6 \mathrm{~A}) *$ \\
\hline
\end{tabular}


detachment of the dentulous portion of the maxilla from the skull roof in this region. Larger temnospondyl skulls can be variably fragmented, but they are rarely observed in this specific fashion where the roof is nearly complete, but without a trace of the palate or neurocranium. This hints at breakage along a plane of weakness, perhaps due to a lack of marked ossification and articulation between different skeletal regions.

Previous authors have not commented on specific features that might indicate relative maturity for AMNH FARB 9503, and no feature observed here indicates as such. If $\mathrm{AMNH}$ FARB 9503 was a lydekkerinid, it would be a "sub-adult" at most based on the size range of the most abundantly known taxon, Lydekkerina huxleyi. As mentioned in the description, it is not possible to characterize the evenness of the ornamentation across the skull, and regions where growth zones (indicating either immaturity or marked paedomorphosis) tend to occur (e.g., cheek region) do not have good surface resolution. Features related to the palate, neurocranium, or postcrania cannot be assessed. Other cranial features are of limited utility because they require taxonomic context (e.g., depth of otic notch, development of tabular horn); the "adult" condition of one taxon may only be the "juvenile" condition of another, especially among temnospondyls in which paedomorphosis is common.

Taxonomic affinities of 'Cryobatrachus kitchingi' based on AMNH FARB 9503.-CPrevious discussion of the taxonomy of 'Cryobatrachus kitchingi' (mostly viz. the holotype) has centered on whether it is a relatively mature lydekkerinid (as argued by Colbert and Cosgriff, 1974) or a juvenile of a much larger stereospondyl, either a capitosaur or a benthosuchid trematosaur (as suggested by Schoch and Milner, 2000, who placed it as Stereospondyli incertae sedis). Here we discuss all temnospondyl clades known from the Early Triassic to be as thorough as possible in our assessment. The primary motivation is to confidently exclude (or to state when we cannot) all clades that are presently recognized from the Early Triassic (mostly stereospondyl clades) to avoid preconceived biases and to explicitly state our lines of reasoning to make them more accessible to broader audiences. One important consideration is that size alone should not be used to exclude some clades in the identification of small-bodied individuals. Small, juvenile individuals of many large-bodied taxa are unknown, and the understanding of ontogenetic transformations in most clades is limited to a handful of well-known taxa (e.g., Bystrow and Efremov, 1940; Welles and Cosgriff, 1965; Steyer, 2003). Figure 9 includes 11 similarly sized specimens representing most of the stereospondyl clades for comparison. The following comparisons focus on qualitative aspects of the skull to avoid an overreliance on the uncertain sutures of AMNH FARB 9503.

All previous workers have assumed that AMNH FARB 9503 is a stereospondyl, but the uninformative nature of the specimen questions this assumption. Most synapomorphies of Stereospondyli pertain to the palate (e.g., Yates and Warren, 2000; McHugh, 2012; Schoch, 2013; Eltink et al., 2019), which is entirely absent. The recent stereospondylomorph analysis by Eltink et al. (2019) recovered a few synapomorphies of Stereospondyli that can be identified in AMNH FARB 9503. These include a parabolic preorbital region; a naris at the same level of the dorsal rostral plane; snout margins continually converging towards the tip; and a slit-like otic notch. Only one synapomorphy (intranarial width greater than interorbital width) is in conflict with AMNH FARB 9503. Because the apomorphies of Stereospondyli are continually being refined, perhaps the strongest argument in support of stereospondyl affinities is the evidence against close relatedness to either of the rare nonstereospondyl clades found in the Triassic: Amphibamiformes and Dvinosauria. These are discussed further below.

Brachyopoids and dvinosaurs are readily excluded on the basis of the relatively long and slender profile of AMNH FARB 9503 (e.g., Warren, 1998a; Warren and Marsicano, 2000; Schoch and Milner, 2014) and are not shown in Figure 9. All brachyopoids have short and wide (brachycephalic) skulls with parabolic outlines. The handful of dvinosaurs with similarly slender skulls (e.g., Erpetosaurus Moodie, 1909, Neldasaurus Chase, 1965; Milner and Sequeira, 2011; Schoch, 2018) are restricted to the late Carboniferous and early Permian, and this clade is rare in the Mesozoic, especially in southern Pangea where the only occurrence is Thabanchuia oomie from South Africa. While other dvinosaurs lack the markedly brachycephalic, parabolic skulls of brachyopoids, their wide snouts and anteriorly positioned orbits are in contrast to other highly nested stereospondyls and to AMNH FARB 9503. Instead, they are more similar to the metoposaurid trematosaurs, with which they were often historically allied (e.g., Säve-Söderbergh, 1935; Shishkin, 1973; Hunt, 1993). Most brachyopoids and dvinosaurs also lack a well-developed otic notch (but see Neldasaurus as a counterpoint). Relatively small specimens, such as the holotypes of T. oomie and 'Platycepsion wilkinsoni' Stephens, 1887, are similar in morphology to larger specimens (either conspecifics or different taxa; Cosgriff, 1969, 1973; Warren, 1998a; Warren and Marsicano, 1998). This includes the Late Triassic form Chinlestegophis jenkinsi.

Amphibamiforms are a relict clade that, unlike dvinosaurs, is documented from the lower Fremouw Formation in the form of Micropholis stowi (Gee and Sidor, 2021; Fig. 9.4), a taxon primarily known from two morphs from South Africa (Boy, 1985; Schoch and Rubidge, 2005). The broad-headed morph, the only form known from Antarctica, has a proportionately shorter and wider skull than AMNH FARB 9503, and the tabular horns are not nearly as developed. All Antarctic specimens also have a biconcave occipital margin, although this occurs less frequently in the South African material. The slenderheaded morph (Fig. 9.4) has a narrower posterior skull table than either the other morph or AMNH FARB 9503. Both morphs have a relatively wide interorbital region with relatively large orbits in the anterior half of the skull. The ornamentation of AMNH FARB 9503 can be sufficiently resolved to determine that it is not pustular, a distinctive feature of $M$. stowi. The otic notch is well developed in $M$. stowi, with a large unornamented, vertically oriented supratympanic flange that may have held a tympanum; this is not preserved in AMNH FARB 9503, which seems to have been genuinely flat in occipital profile. There is no evidence for a lateral exposure of the palatine (LEP) found in many dissorophoids like $M$. stowi; this exposure is often marked by a distinct depression (e.g., Bolt, 1974).

Lapillopsids are an enigmatic clade of diminutive stereospondyls of similar size to amphibamiforms (Fig. 9.5, 9.6). 
1
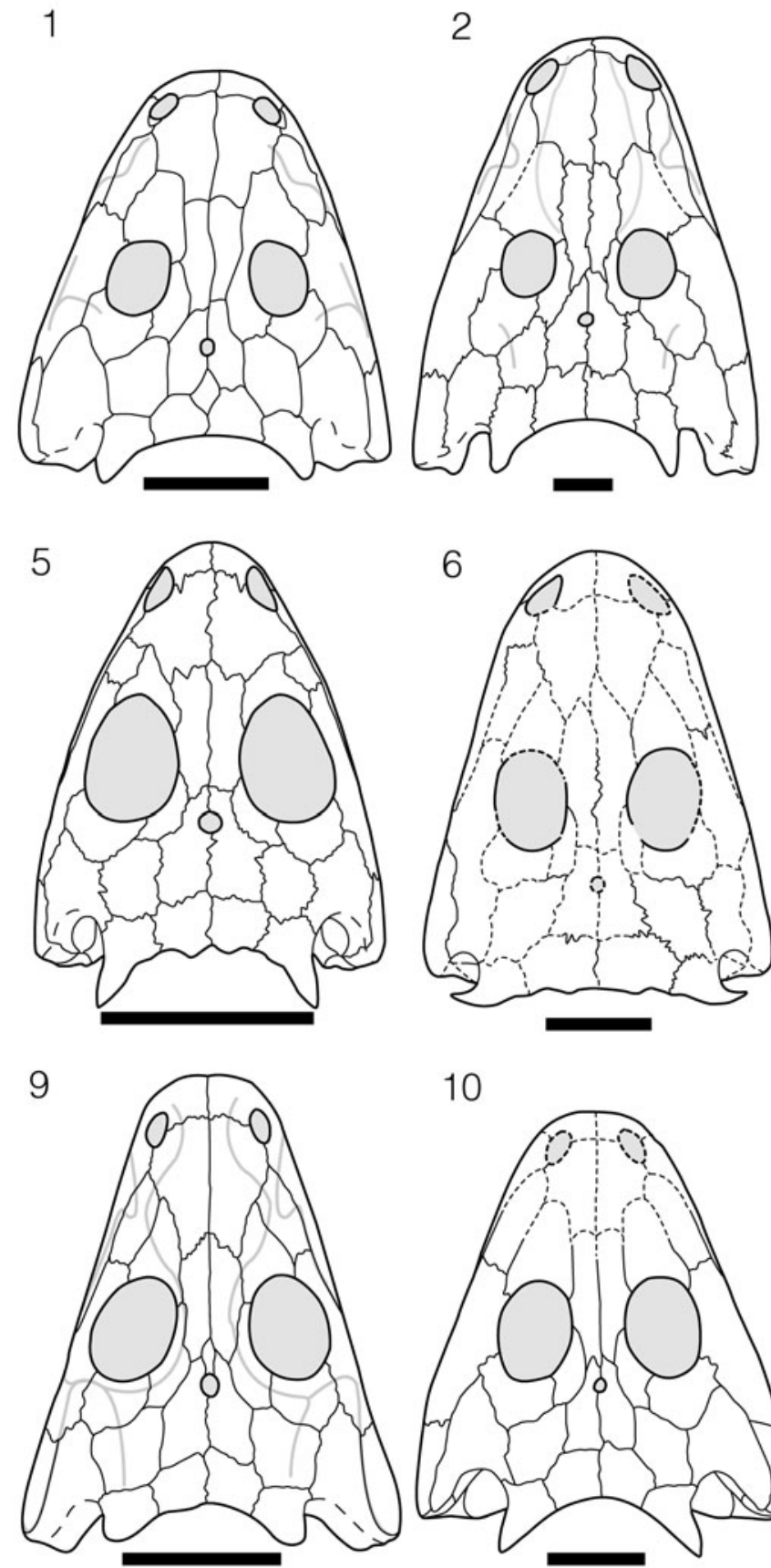

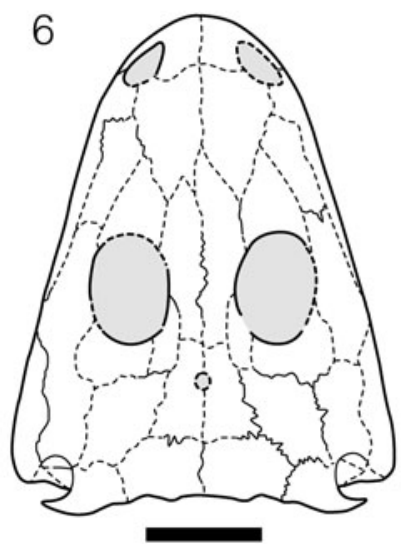

10

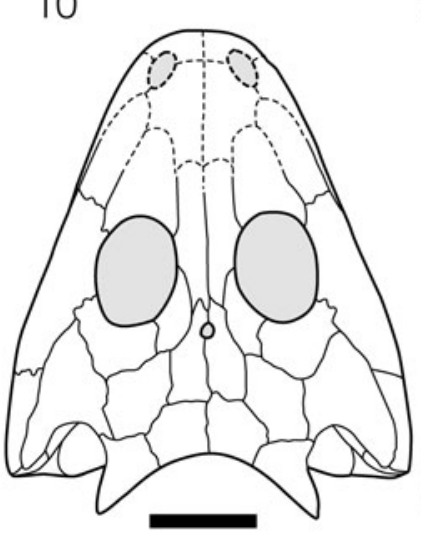

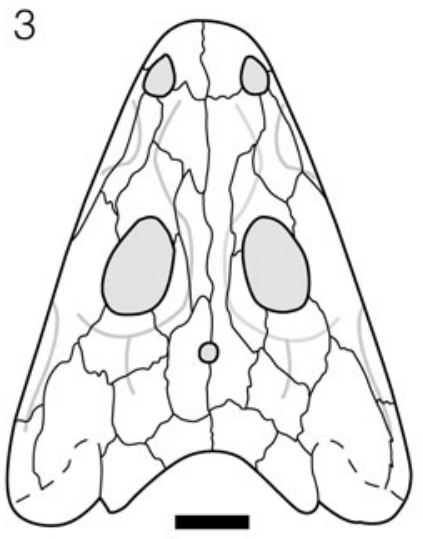
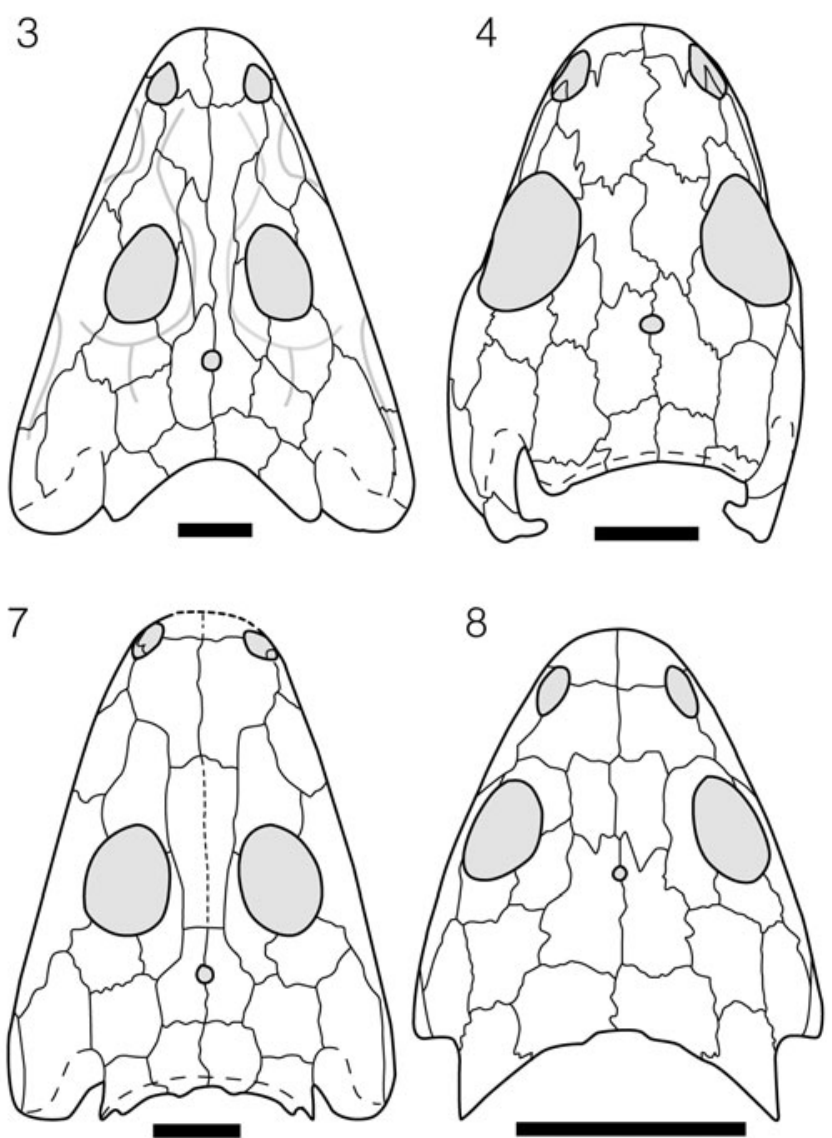

11

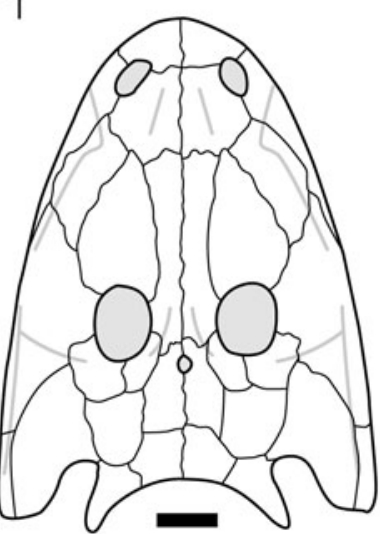

12

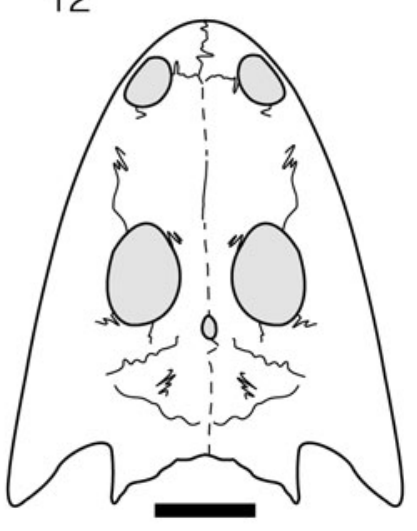

Figure 9. Comparison of cranial reconstructions of various small-bodied temnospondyls from the Lower Triassic. (1) Immature stage of the lydekkerinid Lydekkerina huxleyi (after Schoch and Milner, 2000, fig. 57); (2) mature stage of L. huxleyi (after Schoch and Milner, 2000, fig. 57); (3) the lydekkerinid Chomatobatrachus halei (after Schoch and Milner, 2000, fig. 58); (4) slender-headed morph of the amphibamiform Micropholis stowi (after Schoch and Rubidge, 2005, fig. 2A); (5) relatively mature stage of the lapillopsid Lapillopsis nana (after Yates, 1999, fig. 5A); (6) the lapillopsid Rotaurisaurus contundo (after Yates, 1999, fig. 15A); (7) relatively immature stage of the rhinesuchid Broomistega putterilli (after Shiskin and Rubidge, 2000, fig. 3A); (8) the rhytidosteid Nanolania anatopretia (after Yates, 2000, fig. 4A); (9) immature stage of the trematosaur Benthosuchus sushkini (after Bystrow and Efremov, 1940, fig. 56); (10) immature stage of the capitosaur Watsonisuchus aliciae Warren and Hutchinson, 1988 (after Warren and Hutchinson, 1988, fig. 4A); (11) immature stage of the capitosaur 'Parotosaurus wadei' (after Warren and Hutchinson, 1988, fig. 11C); (12) new reconstruction of AMNH FARB 9503. Scale bars = $1 \mathrm{~cm}$. Fine dashed lines represent inferred sutures; coarse dashed lines represent topographic features.

They occur in both Australia and India, and they were only documented subsequent to the description of 'Cryobatrachus kitchingi' (Warren and Hutchinson, 1990a; Yates, 1999; Yates and Sengupta, 2002). Essentially all of the diagnostic features of the clade (sensu Yates, 1999) are largely based on skeletal regions that were not preserved in this specimen, but there are numerous differences from the two taxa for which cranial material is known. For example, in Lapillopsis nana, the occipital margin is biconcave, the quadratojugal terminates anterior to the posterior termination of the tabular horn, and there is no dorsal swelling posterior to the naris (Fig. 9.5). In Rotaurisaurus contundo Yates, 1999, the tabular horns curve sharply laterally, 
and the occipital margin is nearly horizontal (Fig. 9.6). AMNH FARB 9503 is larger than any known lapillopsid. Although there is doubt over whether the largest specimens of L. nana were adults, the dorsal protuberances on the skull roof and the ontogenetic shift from a sharply concave to relatively flat occipital margin in L. nana indicate that AMNH FARB 9503 is not simply a large specimen of $L$. nana. The proportions of $R$. contundo are very similar to those of AMNH FARB 9503 (Table 1) despite their similar size and underscores the challenges of differentiating small-bodied adults from juveniles on the basis of proportions alone.

Rhytidosteids are a diverse clade that appeared in the late Permian (Marsicano and Warren, 1998), but which are mostly known from the Early Triassic (Dias-da-Silva and Marsicano, 2011). Rhytidosteids would be predicted in Antarctica based on abundant occurrences in southern Pangea, including the Lystrosaurus declivis Assemblage Zone of South Africa (Cosgriff and Zawiskie, 1979; Dias-da-Silva and Marsicano, 2011; Botha and Smith, 2020), the Sakamena Formation of Madagascar (Lehman, 1966), several formations from Australia (Cosgriff, 1965, 1974; Howie, 1972; Warren and Black, 1985; Warren and Hutchinson, 1987; Marsicano and Warren, 1998), and the Sanga do Cabral Formation of Brazil (Dias-da-Silva et al., 2005, 2006). Indeed, Cosgriff and Hammer (1984) referred three ornamented dermal fragments from the lower Fremouw Formation to Rhytidosteidae, but more substantial remains are unknown. Rhytidosteids have a wide range of skull shapes (Dias-da-Silva and Marsicano, 2011, fig. 1), and all taxa have a preorbital region subequal in length to the postorbital region. However, most taxa have triangular skulls with prominent expansion of the temporal region and distinctive posterior projection of the quadratojugal (e.g., Deltasaurus kimberlyensis Cosgriff, 1965). Some are represented by small specimens, in particular Nanolania anatopretia Yates, 2000, from the Arcadia Formation of Australia ( $2 \mathrm{~cm}$ skull length; Yates, 2000; Fig. 9.8), which has the skull profile most similar to that of AMNH FARB 9503. Dias-da-Silva and Marsicano (2011) identified three ambiguous synapomorphies and one unambiguous synapomorphy of Rhytidosteidae in their review. Of these, one is present in AMNH FARB 9503 (orbits located about halfway along the skull length), two are confidently absent (interorbital distance $>50 \%$ of the skull width; 'spider-web' pattern of ornamentation), and one cannot be assessed (pterygoid quadrate ramus orientation). Well-developed otic notches like those of AMNH FARB 9503 are also absent in most rhytidosteids.

Rhinesuchids have only one Mesozoic representative, Broomistega putterilli, from the LAZ of South Africa (Shishkin and Rubidge, 2000; Fig. 9.7), but the group is well documented in the Permian of Brazil (Barbarena, 1998; Barbarena and Dias, 1998; Dias and Richter, 2002; Dias and Schultz, 2003; Ramos and Vega, 2011; Eltink and Langer, 2014; Cisneros et al., 2015; Eltink et al., 2016; Azevedo et al., 2017; Dias et al., 2020) and South Africa (Watson, 1962; Damiani and Rubidge, 2003; Damiani, 2004; Pawley and Warren, 2004; Marsicano et al., 2017). Rhinesuchids have an overall skull profile comparable to that of AMNH FARB 9503 in being long, modestly slender, and with gradual and slight expansion in the temporal region (e.g., Schoch and Milner, 2000, fig. 55; Marsicano et al., 2017). The features used by Colbert and Cosgriff (1974, p. 22) to differentiate 'Cryobatrachus kitchingi' from rhinesuchids were based on comparisons with large individuals (e.g., markedly longer preorbital region, quadrate well posterior to level of tabular). These features are, in fact, shared with juvenile rhinesuchids (e.g., Schoch and Milner, 2000, fig. 55D, E), including individuals of $B$. putterilli (Shishkin and Rubidge, 2000). Rhinesuchids have been previously noted to be difficult to differentiate from lydekkerinids when comparing disparately sized individuals; $B$. putterilli originally was described as a species of Lydekkerina. Shishkin and Rubidge (2000, p. 665) proposed that paedomorphosis produced a higher degree of similarity of $B$. putterilli to juvenile capitosaurs compared to adult rhinesuchids, and the juveniles of $B$. putterilli therefore share many features with adult lydekkerinids (Shishkin and Rubidge, 2000, p. 654). It is not possible to assess any of the formal diagnostic features of Rhinesuchidae listed by Marsicano et al. (2017).

The main features of AMNH FARB 9503 that discount rhinesuchid affinities are the narrow interorbital region, the position of the orbits (they are more posteriorly situated in rhinesuchids, even in similarly sized juveniles), the well-developed tabular horn, which is offset from the main body of the tabular, and the apparent absence of any lateral line grooves on the snout (although such grooves are absent in the smallest specimens of B. putterilli). The nares appear to be entirely dorsally facing, rather than anterolaterally (a rhinesuchid synapomorphy, per Eltink et al., 2019). The prenarial portion of AMNH FARB 9503 is also relatively long compared to juvenile rhinesuchids (e.g., Shishkin and Rubidge, 2000), although Eltink et al. (2019) listed a prenarial region as long or longer than the naris as a rhinesuchid synapomorphy.

Trematosaurs are one of the most widely distributed clades, although they have never been reported from Antarctica, which is surprising in light of their occurrences in adjacent regions of southern Pangea (South Africa, Australia, Madagascar, India). This clade is well known for the longirostrine morphology of later diverging forms, which is absent in AMNH FARB 9503, although this conceivably becomes pronounced throughout ontogeny. Many trematosaurs also have relatively small orbits that are widely spaced compared to AMNH FARB 9503. The earliest stages of trematosaur ontogeny are poorly known outside of Benthosuchus sushkini (Bystrow and Efremov, 1940; Fig. 9.9). Its early diverging position accords with its similarity to early diverging capitosaurs, especially with respect to the relatively short snout, and the taxon was sometimes classified as a capitosaur (e.g., Yates and Warren, 2000; Damiani, 2001). The point here is only that it is not necessarily a good representative of trematosaur ontogeny with respect to cranial allometry and, in fact, seems to share more aspects with capitosaurs (e.g., Welles and Cosgriff, 1965). While Schoch and Milner (2000) suggested benthosuchid affinities as one possibility for 'Cryobatrachus kitchingi,' benthosuchids are only known from Russia. The general skull profile of AMNH FARB 9503 is proportionately wider than that observed in similarly sized individuals of B. sushkini (Bystrow and Efremov, 1940; Fig. 9.9). Other relatively small trematosaur specimens, such as the holotype of Prothoosuchus blomi Getmanov, 1989, have skulls with concave lateral margins and more laterally situated orbits (Schoch 
and Milner, 2000). Small-bodied Late Triassic taxa (e.g., Rileymillerus cosgriffi Bolt and Chatterjee, 2000, and Almasaurus habbazi), which have sometimes been placed with trematosaurs (e.g., Schoch and Milner, 2000; Schoch, 2008a; but see Pardo et al., 2017), have slender, tall skulls with laterally facing orbits. Trematosaurs from other southern Pangean regions are represented by either much larger material (e.g., Warren, 2012) or very fragmentary material (e.g., Damiani et al., 2000; Damiani and Welman, 2001), and all of them are markedly morphologically distinct from AMNH FARB 9503 with respect to the cranial proportions.

With the previous clades excluded, only capitosaurs and lydekkerinids (exclusive of lapillopsids in this specific context) remain as candidate groups (Fig. 9.1, 9.2, 9.10, 9.11). Colbert and Cosgriff $(1974$, p. 22) listed the short preorbital region as the "prime feature" that identifies AMNH FARB 9503 as a lydekkerinid. They derived this from a dated diagnosis of Lydekkerinidae (Watson, 1919; Romer, 1947), which listed the orbits being at the mid-length of the skull. This characterization is generally true of lydekkerinids (Fig. 9.1, 9.2), although it cannot account for possible ontogenetic changes, either known or presently unknown, and the orbits of the relatively large Eolydekkerina magna Shishkin, Rubidge, and Kitching, 1996, are slightly in the posterior half. However, the orbits of AMNH FARB 9503 are clearly not at the mid-length of the skull (Fig. 5; Table 1); in this, the specimen is similar to juveniles of large-bodied taxa and not to small-bodied forms like lydekkerinids.

Colbert and Cosgriff (1974, p. 21-22) also listed other partially differential features, such as the position of the jaw articulation relative to the neck articulation and the position of the posterior termini of the quadratojugal and the tabular. For one, neither the jaw articulation (viz. the lower jaw or the quadrate) nor the neck articulation (viz. the occiput or an articulated atlas) are actually preserved in AMNH FARB 9503. Both of these features are also not diagnostic, and there is biological variation within Lydekkerinidae and taphonomic variation within Lydekkerina huxleyi (e.g., compare holotypes of 'Limnoiketes paludinatans' and Ly. huxleyi; Jeannot et al., 2006). The skull shape is closer to that of some capitosaurs in having a relatively pointed (not blunted) snout and slightly convex lateral margins, but there is enough taphonomic variation within L. huxleyi and enough ontogenetic and interspecific variation within Capitosauria to limit the utility of this comparison. The narrow interorbital region is a more reliable feature that is found in capitosaurs (Fig. 9.10, 9.11), but not in lydekkerinids (Table 1). Also worth noting is the absence of an interorbital depression ('hollow') or raised orbital rims-features found in many lydekkerinids, including the South African taxa (Shishkin et al., 1996; Jeannot et al., 2006; Hewison, 2007). A prominent tabular horn like that of AMNH FARB 9503 is only found in some lydekkerinids (Deltacephalus whitei Swinton, 1956, Eolydekkerina magna, L. huxleyi), but it is found in all capitosaurs. Lastly, the nostrils are relatively large, which is more like capitosaurs than lydekkerinids. These comparisons are only further exemplified when comparing AMNH FARB 9503 to the most similarly sized lydekkerinids (Fig. 9.1, 9.2). The presence of a postnarial septomaxilla cannot be confirmed, nor can the exclusion of the frontal from the orbit. While large capitosaurs have a fully-developed lateral line system, it seems to be absent in juveniles of some taxa (e.g., Warren and Hutchinson, 1988, but see Steyer, 2003), whereas even relatively small lydekkerinids have moderately developed canals on the snout (e.g., Hewison, 1996, 2007; Jeannot et al., 2006). Possibly, the organ overlay the skull in AMNH FARB 9503, but was not yet impressed into the roofing elements (see discussion by Witzmann et al., 2010). No diagnostic feature of lydekkerinids (Jeannot et al., 2006; Eltink et al., 2019) is preserved in AMNH FARB 9503, although many of these relate to skeletal regions that are absent in this specimen. The diagnosis of Capitosauria cannot be properly considered here since apomorphies could be absent in juveniles. Most of the diagnostic features listed by previous authors cannot be assessed, whether they are purported apomorphies (e.g., Yates and Warren, 2000; Schoch, 2008b) or part of a unique combination of features (e.g., Schoch and Milner, 2000; Damiani, 2001; Steyer, 2003).

If AMNH FARB 9503 were a lydekkerinid, it could range from a relatively mature 'sub-adult' to a fully mature adult based on the size of other southern Pangean lydekkerinids. Therefore, it is reasonable to expect certain characteristics (such as the interorbital hollow) in a lydekkerinid of this size. Evidence for this is observed in the small holotype of Deltacephalus whitei $(<5 \mathrm{~cm}$ in skull length; Hewison, 1996) and the holotype of 'Limnoiketes paludinatans' $(5.5 \mathrm{~cm}$ skull length, a relatively small individual of Lydekkerina huxleyi). Conversely, if AMNH FARB 9503 were a capitosaur, it would undoubtedly be a very immature individual, because capitosaurs frequently exceeded half a meter in skull length. Therefore, it is less reasonable to expect certain characteristics (e.g., the prominent Z-shaped lacrimal flexure of the supraorbital canal) in a capitosaur of this size. In this specific example, lateral line grooves appear to have been absent from the skull roof entirely in very immature individuals of some capitosaurs (Warren and Hutchinson, 1988). On the balance of evidence against affinities with other clades, a few qualitative similarities with juvenile capitosaurs, and evidence against capitosaur affinities, we tentatively conclude that AMNH FARB 9503 is the juvenile of an indeterminate capitosaur, which is one of the two possibilities hypothesized by Schoch and Milner (2000) and the one briefly alluded to by Sidor et al. (2007, p. 232). AMNH FARB 9503 can more confidently be maintained as a nomen dubium (following Schoch and Milner, 2000), because the specimen is largely uninformative in the absence of verified sutures, and what can be verified is not diagnostic.

Ontogenetic interpretation of FMNH PR 5020.-A few features hint at the relative maturity of FMNH PR 5020. The first line of evidence is the evenness of the ornamentation - certain regions of the temnospondyl skull frequently show radiating ornamentation in the form of grooves or ridges in early stages of development, reflecting rapid zones of growth (e.g., Bystrow, 1935; Bystrow and Efremov, 1940; Getmanov, 1989; Boy and Sues, 2000; Witzmann et al., 2010). Such zones are most common in the preorbital and cheek regions where positive allometry is noted (e.g., Bystrow, 1935; Witzmann and Scholz, 2007; Witzmann et al., 2010); in the preserved preorbital region of this specimen, the ornamentation is not radiating. The second line of evidence is the small size of the 
orbits (see previous discussion of AMNH FARB 9503). Even if the skull were to terminate just posterior to the posteriormost preserved region (resulting in a highly irregular shape), the orbits would still be proportionately quite small. A possible third feature is the absence of sutures. Preservation of the specimen is relatively good with many of the small nutrient foramina being identifiable (i.e., the ornamentation is not badly damaged from preparation or weathering), so the sutures could have been indistinguishably fused, at least dorsally (e.g., Kathe, 1999). The last and perhaps most robust line of evidence is the anterior ossification of the sphenethmoid in the interorbital region. The sphenethmoid tends to either complete ossification only at relatively late stages of ontogeny, or not at all, in stereospondylomorphs (e.g., Bystrow and Efremov, 1940; Welles and Cosgriff, 1965; Schoch, 2002; Witzmann, 2005, 2006; Schoch and Witzmann, 2009a, b). This feature is expanded upon below.

The neurocranium of stereospondyls is best known from capitosaurs, with excellent descriptions of Mastodonsaurus giganteus Jaeger, 1828, by Schoch (1999, 2002), but these are based mainly on the relatively large specimens of this taxon. Other taxa provide evidence for an ontogenetic transformation of the sphenethmoid. In Wellesaurus peabodyi Welles and Cosgriff, 1965, there is no sphenethmoid in a skull of $26 \mathrm{~cm}$ in length, a partially ossified sphenethmoid in a skull of $33 \mathrm{~cm}$ in length, and a well-ossified sphenethmoid in a skull of $44 \mathrm{~cm}$ in length (the largest known for the taxon; Welles and Cosgriff, 1965). A very short $(3 \mathrm{~cm})$ sphenethmoid ossification, incomplete and well posterior to the interorbital region, is known in the $\sim 24 \mathrm{~cm}$ long holotype skull of Watsonisuchus rewanensis Warren, 1980. A similarly positioned, poorly ossified sphenethmoid is found in the holotype of Watsonisuchus gunganj Warren, 1980 (22.7 cm skull length). No sphenethmoid is apparent in the nearly complete and undistorted holotype of Stanocephalosaurus amenasensis Dahoumane et al., 2016, which is estimated to be $\sim 23 \mathrm{~cm}$ in length and which was tomographically analyzed by Arbez et al. (2017). Some remnant of the sphenethmoid is found in the specimens of Edingerella madagascariensis (Lehman, 1961), which are all small and which range from 4.6-14.9 cm (Lehman, 1961; Steyer, 2003; Maganuco et al., 2009). However, the sphenethmoid is posteriorly restricted and poorly ossified in these individuals (evinced by the scant morphological characterization of previous workers), and various features, such as the absence of a complete lateral line system, set FMNH PR 5020 apart from this taxon. The sphenethmoid is unknown for most trematosaurs, in spite of the large size of many specimens and a large sample size for some taxa (e.g., Trematosaurus brauni Burmeister, 1849; Schoch, 2019), and it remained unossified in the metoposaurid trematosaurs. In Benthosuchus sushkini, the sphenethmoid appears to begin ossifying at a skull length of $\sim 30 \mathrm{~cm}$; this is less than half of the largest estimated size $(\sim 80 \mathrm{~cm})$, but is also several times larger than FMNH PR 5020 (Bystrow and Efremov, 1940). A well-ossified sphenethmoid is only known in a handful of relatively large plagiosaurid specimens among the brachyopoids (e.g., Damiani et al., 2009; Witzmann et al., 2012). There is scant data on the neurocranium of lapillopsids, rhinesuchids, and rhytidosteids. By comparison, a well-ossified sphenethmoid extending to the interorbital region is found in the putative "adults" of small-bodied clades (e.g., lydekkerinids; Shishkin et al., 1996; Jeannot et al., 2006) and nonbranchiosaurid amphibamiforms (e.g., Schoch and Rubidge, 2005; Sigurdsen and Bolt, 2010; Bourget and Anderson, 2011; Maddin et al., 2013). The presence of this ossification evinces maturation at small size in these clades. Collectively, the presence of a well-ossified sphenethmoid that reached at least the interorbital region strongly suggests that FMNH PR 5020 matured at a small size $(<15 \mathrm{~cm}$ in skull length).

Taxonomic interpretations of FMNH PR 5020.- - In the absence of sutures, the interpretations of this specimen are based on qualitative features and our ontogenetic assessment. As we noted above, FMNH PR 5020, with a maximum preserved length of $7.3 \mathrm{~cm}$, appears to have been relatively mature at the time of death, thereby restricting the candidate clades to relatively small-bodied clades (adult skull length $<15 \mathrm{~cm}$ ). The preserved portions of the skull also indicate that the specimen does not belong to a brachycephalic clade with a short and broad skull (e.g., plagiosaurids such as Gerrothorax pulcherrimus Fraas, 1913). In the Lower Triassic, the group of candidates thus encompasses amphibamiforms, lapillopsids, lydekkerinids, rhinesuchids, and rhytidosteids, which is a fortuitously narrow taxon bracket for evaluating FMNH PR 5020.

Amphibamiforms are only confidently represented in the Lower Triassic by Micropholis stowi, which was recently documented from the lower Fremouw Formation (Gee and Sidor, 2021). FMNH PR 5020 is clearly not M. stowi, because it lacks the apomorphic pustulated ornamentation that covers the skull of $M$. stowi. The skull is also flat, with gently curved lateral surfaces, rather than the taller profile observed in terrestrial dissorophoids. This includes the anterolateral corner of the orbit. In dissorophoids with a large lateral exposure of the palatine (LEP), which occurs in $M$. stowi, the skull roof is prominently depressed in this area (e.g., Bolt, 1974), but this region is flat in FMNH PR 5020. The suborbital bar is also taller (wider) than in small-bodied dissorophoids such as M. stowi (e.g., Schoch and Rubidge, 2005). Thirdly, the orbits of amphibamiforms remain relatively large throughout ontogeny, which has been ascribed to miniaturization and consequent reduction in size of the circumorbital bones (e.g., Schoch and Rubidge, 2005; Pérez-Ben et al., 2018). The orbits of FMNH PR 5020 are proportionately much smaller regardless of the complete size of the individual. Finally, $M$. stowi is known from abundant remains across the Karoo Basin, in which the largest specimen does not exceed $4.5 \mathrm{~cm}$ in midline length. Micropholis stowi is already one of the largest amphibamiforms, being surpassed only by some other micropholid amphibamiforms (e.g., Pasawioops mayi Fröbisch and Reisz, 2008; Maddin et al., 2013), whose largest known size is distinctly less than the preserved length of FMNH PR 5020.

Lapillopsids encompass only small-bodied taxa, $<4.5 \mathrm{~cm}$ in skull length, and they have proportionately large orbits, in stark contrast to FMNH PR 5020 (Warren and Hutchinson, 1990a; Yates, 1999; Yates and Sengupta, 2002). The preserved skull profile of FMNH PR 5020 is somewhat comparable to that of Lapillopsis nana, so there is again the question of whether the largest known specimens of this taxon are only "juveniles" or 
"subadults" (Yates, 1999). However, FMNH PR 5020 lacks the dorsal swelling posterior to the naris that diagnoses L. nana; as ornamentation tends to become more pronounced throughout temnospondyl ontogeny, it would not be expected for the feature to retrograde into a flatter skull roof. FMNH PR 5020 also lacks pustular ornamentation, which would be expected to be more developed in a mature individual of L. nana. The holotype of $R$. contundo is similar to FMNH PR 5020 only in having proportionately smaller orbits. Unfortunately, the diagnostic features of this taxon are on areas not preserved in FMNH PR 5020. The best lines of evidence against affinities with $R$. contundo are the profile in dorsal view-broader expansion posteriorly in FMNH PR 5020, with obliquely oriented orbits - and the presence of (at least) an infraorbital lateral line groove in FMNH PR 5020 (lateral line grooves are unknown in any lapillopsid).

Rhytidosteids include a number of taxa known from skulls of a similar length to the inferred complete size of FMNH PR 5020, including some from Lower Triassic rocks of Australia (e.g., Cosgriff, 1965; Cosgriff and Zawiskie, 1979; Warren and Black, 1985; Warren and Hutchinson, 1987; Yates, 2000). However, all rhytidosteids can be confidently excluded on the basis of their characteristic wide interorbital distance and the absences of the so-called 'spider web' pattern of ornamentation with pitting radiating outward into a groove-ridge system (Dias-da-Silva and Marsicano, 2011).

Lydekkerinids and rhinesuchids are the final groups to warrant consideration. Most rhinesuchids are known from much larger specimens ( $>20 \mathrm{~cm}$ skull length), but those of the only Triassic representative, Broomistega putterilli, are similar in size to large lydekkerinids (Shishkin and Rubidge, 2000). Most lydekkerinids are smaller than FMNH PR 5020, but there are some specimens of both Lydekkerina huxleyi and Eolydekkerina magna in the same range (the disputed long-snouted lydekkerinids Chomatobatrachus halei and Luzocephalus have much longer skulls; Cosgriff, 1974; Shishkin, 1980). One feature probably shared with both groups is a dorsal exposure of the septomaxilla posterior to the naris. The damage in this region on the left side of FMNH PR 5020 is similar to specimens of $L$. huxleyi in which the septomaxilla has been lost (e.g., Jeannot et al., 2006; Hewison, 2007). The skull shape and the small, obliquely oriented orbits align more closely with lydekkerinids, particularly those from South Africa. Other shared features include the uniform distribution of relatively shallow pitted ornamentation, without any zones of intensive growth (marked by striating grooves or ridges), but with distinct nodes at the intersections, and the poorly developed and discontinuous lateral line system (most similar to Lydekkerina huxleyi). Although the supraorbital canals are not fully exposed, and their relationship to specific cranial elements is unknown, the left canal does have a medial step (flexure) at the presumed position of the lacrimal (posterior to the naris), a feature not found in rhinesuchids, but common in lydekkerinids (Shishkin et al., 1996). Jeannot et al. (2006) expressly lists this as a lydekkerinid symplesiomorphy while Hewison (2007) lists it as a synapomorphy found in the majority of lydekkerinids (bearing in mind his more restrictive composition of the clade). One other feature of note is that the interorbital region of FMNH PR 5020 is shallowly depressed, with the left orbital rim being dorsally offset. Shishkin and Rubidge (2000, p. 656) noted this as a differentiating feature of lydekkerinids relative to rhinesuchids. The same feature (termed an 'interorbital hollow'; see Shishkin, 1980, p. 91, for early usage) was also noted by Piñeiro et al. (2012, p. 73) within the same comparative framework. Hewison (2007) described this feature in L. huxleyi and 'Limnoiketes paludinatans,' although he noted it was absent in Chomatobatrachus halei and Luzocephalus blomi Shishkin, 1980, neither of which he considered to be lydekkerinids. Regardless of the composition of the Lydekkerinidae, this depression is absent in rhinesuchids, but present in some lydekkerinids, and it thus serves as evidence against a possible interpretation as a diminutive rhinesuchid like $B$. putterilli.

No feature definitively excludes FMNH PR 5020 from the Lydekkerinidae, and we therefore provisionally refer the specimen to Temnospondyli cf. Lydekkerinidae. The absence of sutures, the posterior skull table, and the palate preclude further taxonomic refinement, although we would predict either conspecificity with, or close relatedness to, one of the southern Pangea taxa such as Eolydekkerina or Lydekkerina. Lydekkerina huxleyi is abundant in the Karoo Basin and is also known from Australia (Warren et al., 2006), but autapomorphies of previous authors (e.g., Jeannot et al., 2006) are for skeletal regions not exposed or preserved in FMNH PR 5020. Additionally, there is the conundrum of whether taxonomic differentiators are in part related to size (presumed ontogenetic) differences, which is particularly poignant for differentiating Eolydekkerina magna from L. huxleyi (Pawley and Warren, 2005; Jeannot et al., 2006). FMNH PR 5020 would have been closer in size to the larger $E$. magna than to the majority of specimens and the holotype of L. huxleyi, which might explain why the prenarial region is proportionately longer than in the latter. Eolydekkerina is a valid taxon according to Jeannot et al. (2006), who argued that the size distribution of $L$. huxleyi, for which specimens very rarely approach the size of E. magna, indicates that E. magna is not simply a large individual of L. huxleyi. However, it should be considered that most individuals of L. huxleyi likely did not survive long enough to reach the maximum body size, perhaps due to predation risk as relatively small tetrapods or to climatic harshness. Histological studies have supported this hypothesis through identification of a particularly fast growth rate in early ontogeny and immaturity in specimens that would typically be considered "adult-sized" (Canoville and Chinsamy, 2015; McHugh, 2015).

Lower Fremouw temnospondyl assemblage.-This study continues to refine the poorly understood temnospondyl assemblage of the lower Fremouw Formation that was first characterized in detail by Colbert and Cosgriff (1974) and subsequently expanded upon by Cosgriff and Hammer (1984). Collectively, those workers identified remains of what they considered to be unequivocal brachyopids, unequivocal lydekkerinids, unequivocal rhytidosteids, and equivocal capitosauroids. Occasional mentions of a tupilakosaurid dvinosaur in the lower Fremouw Formation are based on personal observations of unspecified material by Shishkin (e.g., Shishkin, 2003, 2007; Shishkin et al., 2006), but such material has never been described or figured in any capacity, and Tupilakosauridae is not considered to be present in Antarctica at present (Schoch and Milner, 2014). 
The extremely fragmentary nature of practically all of the material has greatly hindered the characterization of the temnospondyl record from this interval at all taxonomic scales. The holotype of 'Austrobrachyops jenseni' is not even a temnospondyl, and the referred material was only identified to Brachyopoidea (not Brachyopidae) by Warren and Marsicano (2000; but see Schoch and Milner, 2014, who do place this material to the family level). Similarly, the holotype of 'Cryobatrachus kitchingi' is interpreted as a juvenile capitosaur by us here, following Schoch and Milner (2000). As we noted in the Materials and Methods, none of the referred material of ' $C$. kitchingi' is properly referable to Lydekkerinidae on the basis of identification of apomorphies. We consider the recognition of Capitosauria in the lower Fremouw Formation viz. AMNH FARB 9503 to be more reliable than the putative capitosauroid based on a single isolated tabular that Colbert and Cosgriff (1974) argued was either a trematosauroid or a capitosauroid. Those workers identified it formally as Temnospondyli incertae sedis; Cosgriff and Hammer (1984) then referred to it specifically as an indeterminate capitosauroid. Schoch and Milner (2000) noted this tabular in their section on indeterminate capitosaur material, but it has otherwise not been further discussed in the literature. Similarly, we consider FMNH PR 5020 to represent the most reliable record of Lydekkerinidae from this horizon, because it is the most substantial and well-preserved of the suite of specimens referred to the clade at any given point. The rhytidosteid fragments reported by Cosgriff and Hammer (1984) have rarely been discussed. Shishkin $(1994,2003)$ expressed skepticism over their identity, and other references to the Antarctic record do not indicate an expressed opinion (e.g., Dias-da-Silva et al., 2006); Schoch and Milner (2000) essentially repeat the original justification of Cosgriff and Hammer (1984).

This collective convoluted history only underscores the need for continued taxonomic work and the essentiality of revisiting historic specimens as taxonomic frameworks shift over time. The recent report of Micropholis stowi, representing the first occurrence of Amphibamiformes in Antarctica, based on recently collected material (Gee and Sidor, 2021) is both the most substantial and the most robust temnospondyl record from the entire lower Fremouw Formation. It is hoped that further collection and study of new material may provide a richer context through which to interpret the historic material.

\section{Acknowledgments}

Thanks to M. Norell, R. O'Leary, and C. Mehling for the loan of AMNH FARB 9503 and for granting permission for CT scanning, as well as J. Maisano and M. Colbert for their valiant efforts to scan this cumbersome specimen. Thanks to C. Mehling for assistance with historic collection numbers. Thanks to W. Simpson, A. Stroup, and A. Shinya for the loan of FMNH PR 5020, to M. London for preparation of this specimen, and to M. Rich for photography. Thanks to the editor, H.-D. Sues, and to E. Eltink and one anonymous reviewer for constructive feedback that improved this manuscript. Fieldwork resulting in the recovery of FMNH PR 5020 was supported by NSF ANT-1341304 and ANT-1341645, with additional research and analysis supported by NSF ANT-1947094.

\section{Data availability statement}

Data available from the Dryad Digital Repository: https://doi. org/10.5061/dryad.j3tx95xfm.

\section{References}

Antczak, M., and Bodzioch, A., 2018, Ornamentation of dermal bones of Metoposaurus krasiejowensis and its ecological implications: PeerJ, v. 6, e5267, https://doi.org/10.7717/peerj.5267.

Arbez, T., Dahoumane, A., and Steyer, J.-S., 2017, Exceptional endocranium and middle ear of Stanocephalosaurus (Temnospondyli: Capitosauria) from the Triassic of Algeria revealed by micro-CT scan, with new functional interpretations of the hearing system: Zoological Journal of the Linnean Society, v. 180, p. 910-929, https://doi.org/10.1093/zoolinnean/zlw007.

Azevedo, K.L., Vega, C.S., and Soares, M.B., 2017, A new specimen of Australerpeton cosgriffi Barberena, 1998 (Stereospondyli: Rhinesuchidae) from the Middle/Upper Permian Rio do Rasto Formation, Paraná Basin, Brazil: Revista Brasileira de Paleontologia, v. 20, p. 333-344, https://doi.org/10. 4072/rbp.2017.3.05.

Barberena, M.C., 1998, Australerpeton cosgriffi n. g., n. sp., a Late Permian Rhinesuchoid amphibian from Brazil: Anais da Academia Brasileira de Ciências, v. 70, p. 125-137.

Barberena, M.C., and Dias, E.V., 1998, On the presence of a short-snouted rhinesuchoid amphibian in the Rio do Rasto Formation (Late Permian of Paraná Basin, Brazil): Anais da Academia Brasileira de Ciências, v. 70, p. 465468.

Barrett, P.J., Baillie, R.J., and Colbert, E.H., 1968, Triassic amphibian from Antarctica: Science, v. 161, p. 460-462, https://doi.org/10.1126/science. 161.3840.460.

Bolt, J.R., 1974, Evolution and functional interpretation of some suture patterns in Paleozoic labyrinthodont amphibians and other lower tetrapods: Journal of Paleontology, v. 48, p. 434-458, https://www.jstor.org/stable/1303132.

Bolt, J.R., and Chatterjee, S., 2000, A new temnospondyl amphibian from the Late Triassic of Texas: Journal of Paleontology, v. 74, p. 670-683, https://doi.org/10.1666/0022-3360(2000)074<0670:ANTAFT>2.0.CO;2.

Botha, J., and Smith, R.M.H., 2020, Biostratigraphy of the Lystrosaurus declivis Assemblage Zone (Beaufort Group, Karoo Supergroup), South Africa: South African Journal of Geology, v. 123, p. 207-216, https://doi.org/10. 25131/sajg.123.0015.

Bourget, H., and Anderson, J.S., 2011, A new amphibamid (Temnospondyli: Dissorophoidea) from the Early Permian of Texas: Journal of Vertebrate Paleontology, v. 31, p. 32-49, https://doi.org/10.1080/02724634.2011. 539652.

Boy, J.A., 1985, Über Micropholis, den letzten Überlebenden der Dissorophoidea (Amphibia, Temnospondyli; Unter-Trias): Neues Jahrbuch für Geologie und Paläontologie-Monatshefte, v. 1985, p. 29-45, https://doi.org/10.1127/ njgpm/1985/1985/29.

Boy, J.A., 1988, Über einige Vertreter der Eryopoidea (Amphibia: Temnospondyli) aus dem europäischen Rotliegend (? höchstes Karbon-Perm) 1. Sclerocephalus: Paläontologische Zeitschrift, v. 62, p. 107-132, https://doi.org/ 10.1007/BF02989838.

Boy, J.A., 1989, Über einige Vertreter der Eryopoidea (Amphibia: Temnospondyli) aus dem europäischen Rotliegend (? höchstes Oberkarbon-Perm) 2. Acanthostomatops: Paläontologische Zeitschrift, v. 63, p. 133-151, https://doi.org/10.1007/BF02989530.

Boy, J.A., 1990, Über einige Vertreter der Eryopoidea (Amphibia: Temnospondyli) aus dem europäischen Rotliegend (? höchstes Karbon-Perm) 3. Onchiodon: Paläontologische Zeitschrift, v. 64, p. 287-312, https://doi.org/10. 1007/BF02985720.

Boy, J.A., 1993, Über einige vertreter der Eryopoidea (Amphibia: Temnospondyli) aus dem europäischen Rotliegend (? höchstes Karbon-Perm) 4. Cheliderpeton latirostre: Paläontologische Zeitschrift, v. 67, p. 123-143, https:// doi.org/10.1007/BF02985874.

Boy J.A., and Sues H.-D., 2000, Branchiosaurs: larvae, metamorphosis and heterochrony in temnospondyls and seymouriamorphs, in Heatwole, H., Carroll, R.L., eds., Amphibian Biology 4: Palaeontology: Chipping Norton, England, Surrey Beatty \& Sons, p. 1150-1197.

Broom, R., 1915, On the Triassic stegocephalians, Brachyops, Bothriceps and Lydekkerina, gen. nov.: Proceedings of the Zoological Society of London, v. 26, p. 363-368, https://doi.org/10.1111/j.1469-7998.1915. tb07600.x.

Broom, R., 1930, Notes on some labyrinthodonts in the Transvaal Museum: Annals of the Transvaal Museum, v. 21, p. 251-252, https://hdl.handle. net/10520/AJA00411752_643.

Burmeister, H., 1849, Die Labyrinthodonten aus dem Bunten Sandstein von Berneburg. I. Abteilung. Trematosaurus: Berlin, Reimer, 71 p. 
Bystrow, A.P., 1935, Morphologische untersuchungen der deckknochen desschädels der wirbeltiere: schädel der stegocephalen: Acta Zoologica, v. 16, p. 65-141, https://doi.org/10.1111/j.1463-6395.1935.tb00664.x.

Bystrow, A.P., and Efremov, J.A., 1940, Benthosuchus sushkini Efremov-a labyrinthodont from the Eotriassic of the Sharzenga River: Trudy Paleontologicheskogo Instituta, v. 10, p. 1-152.

Canoville, A., and Chinsamy, A., 2015, Bone microstructure of the stereospondyl Lydekkerina huxleyi reveals adaptive strategies to the harsh post Permianextinction environment: The Anatomical Record, v. 298, p. 1237-1254, https://doi.org/10.1002/ar.23160.

Chakravorti, S., and Sengupta, D.P., 2018 [for 2019], Taxonomy, morphometry and morphospace of cranial bones of Panthasaurus gen. nov. maleriensis from the Late Triassic of India: Journal of Iberian Geology, v. 45, p. 317340, https://doi.org/10.1007/s41513-018-0083-1.

Chase, J.N., 1965, Neldasaurus wrightae, a new rhachitomous labyrinthodont from the Texas Lower Permian: Bulletin of the Museum of Comparative Zoology, v. 133, p. 156-225.

Cisneros, J.C., Marsicano, C., Angielczyk, K.D., Smith, R.M., Richter, M., Fröbisch, J., Kammerer, C.F., and Sadleir, R.W., 2015, New Permian fauna from tropical Gondwana: Nature Communications, v. 6, 8676. https://doi. org/10.1038/ncomms9676.

Colbert, E.H., and Cosgriff, J.W., 1974, Labyrinthodont amphibians from Antarctica: American Museum Novitates, v. 2552, p. 1-30, http://hdl.handle. net/2246/2750.

Collinson, J.W., Hammer, W.R., Askin, R.A., and Elliot, D.H., 2006, PermianTriassic boundary in the central Transantarctic Mountains, Antarctica: Geological Society of America Bulletin, v. 118, p. 747-763, https://doi.org/10. 1130/B25739.1.

Cosgriff, J.W., 1965, A new genus of Temnospondyli from the Triassic of Western Australia: Journal of the Royal Society of Western Australia, v. 48, p. 65-90.

Cosgriff, J.W., 1969, Blinasaurus, a brachyopid genus from western Australia and New South Wales: Journal of the Royal Society of Western Australia, v. 52, p. $65-88$.

Cosgriff, J.W., 1973, Notobrachyops picketti, a brachyopid from the Ashfield Shale, Wiannamatta Group, New South Wales: Journal of Paleontology, v. 47, p. 1094-1101, https://www.jstor.org/stable/1303172.

Cosgriff, J.W., 1974, Lower Triassic Temnospondyli of Tasmania: The Geological Society of America, Special Paper, v. 149, p. 1-134.

Cosgriff, J.W., and Hammer, W.R., 1984, New material of labyrinthodont amphibians from the Lower Triassic Fremouw Formation of Antarctica: Journal of Vertebrate Paleontology, v. 4, p. 47-56, https://doi.org/10. 1080/02724634.1984.10011985.

Cosgriff, J.W., and Zawiskie, J.M., 1979, A new species of the Rhytidosteidae from the Lystrosaurus Zone and a review of the Rhytidosteoidea: Palaeontologia Africana, v. 22, p. 1-27, http://hdl.handle.net/10539/16282.

Credner, H., 1883, Die Stegocephalen aus dem Rothliegenden des Plauen'schen Grundes bei Dresden: Zeitschrift der Deutschen Geologischen Gesellschaft, v. 35 , p. 576-633.

Dahoumane, A., Nedjari, A., Aït-Ouali, R., Taquet, P., Vacant, R., and Steyer, J.-S., 2016, A new mastodonsauroid temnospondyl from the Triassic of Algeria: implications for the biostratigraphy and palaeoenvironments of the Zarzaitine Series, Northern Sahara: Comptes Rendus Palevol, v. 15, p. 918-926, https://doi.org/10.1016/j.crpv.2015.09.005.

Damiani, R.J., 2001, A systematic revision and phylogenetic analysis of Triassic mastodonsauroids (Temnospondyli: Stereospondyli): Zoological Journal of the Linnean Society, v. 133, p. 379-482, https://doi.org/10.1111/j.10963642.2001.tb00635.x.

Damiani, R.J., 2004, Temnospondyls from the Beaufort Group (Karoo Basin) of South Africa and their biostratigraphy: Gondwana Research, 7, p. 165-173, https://doi.org/10.1016/S1342-937X(05)70315-4.

Damiani, R.J., and Jeannot, A.M., 2002, A brachyopid temnospondyl from the lower Cynognathus Assemblage Zone in the northern Karoo Basin, South Africa: Palaeontologia Africana, v. 38, p. 57-69, http://hdl.handle.net/ $10539 / 16352$.

Damiani, R.J., and Rubidge, B.S., 2003, A review of the South African temnospondyl amphibian record: Palaeontologia Africana, v. 39, p. 21-36, http:// hdl.handle.net10539/13304.

Damiani, R.J., and Warren, A., 1997, Re-interpretation of Parotosuchus wadei Cosgriff, a capitosaurid from the Triassic Narrabeen Group at Gosford, New South Wales, with comments on its growth stage: Alcheringa, v. 21, p. 281289, https://doi.org/10.1080/03115519708619168.

Damiani, R.J., and Welman, J., 2001, A long-snouted trematosaurid amphibian from the Early Triassic of South Africa: South African Journal of Science, v. 97, p. 318-320, https://hdl.handle.net/10520/EJC97343.

Damiani, R.J., and Yates, A.M., 2003, The Triassic amphibian Thoosuchus yakovlevi and the relationships of the Trematosauroidea (Temnospondyli: Stereospondyli): Records of the Australian Museum, v. 55, p. 331-342.
Damiani, R., Neveling, J., Hancox, J., and Rubidge, B., 2000, First trematosaurid temnospondyl from the Lystrosaurus Assemblage Zone of South Africa and its biostratigraphic implications: Geological Magazine, v. 137, p. 659-665, https://doi.org/10.1017/S0016756800004660.

Damiani, R., Schoch, R.R., Hellrung, H., Werneburg, R., and Gastou, S., 2009, The plagiosaurid temnospondyl Plagiosuchus pustuliferus (Amphibia: Temnospondyli) from the Middle Triassic of Germany: anatomy and functional morphology of the skull: Zoological Journal of the Linnean Society, v. 155, p. 348-373, https://doi.org/10.1111/j.10963642.2008.00444.x.

Dias, E.V., and Richter, M. 2002, On the squamation of Australerpeton cosgriff Barberena, 1998, a temnospondyl amphibian from the Upper Permian of Brazil: Anais da Academia Brasileira de Ciências, v. 74, p. 477-490, https://doi.org/10.1590/S0001-37652002000300010.

Dias, E.V., and Schultz, C.L., 2003, The first Paleozoic temnospondyl postcranial skeleton from South America: Revista Brasileira de Paleontologia, v. 6 p. 29-42, http://hdl.handle.net/10183/216743.

Dias, E.V., Dias-da-Silva, S., and Schultz, C.L., 2020, A new short-snouted rhinesuchid from the Permian of southern Brazil: Revista Brasileira de Paleontologia, v. 23, p. 98-122, https://doi.org/10.4072/rbp.2020.2.03

Dias-da-Silva, S., and Hewison, R., 2013, Phylogenetic analysis and palaeobiogeography of the Pangaean Lower Triassic Lydekkerinidae (Temnospondyli, Stereospondyli): Society of Vertebrate Paleontology, $73^{\text {rd }}$ Annual Meeting Program, p. 116.

Dias-da-Silva, S., and Marsicano, C., 2011, Phylogenetic reappraisal of Rhytidosteidae (Stereospondyli: Trematosauria), temnospondyl amphibians from the Permian and Triassic: Journal of Systematic Palaeontology, v. 9, p. 305-325, https://doi.org/10.1080/14772019.2010.492664.

Dias-da-Silva, S., Marsicano, C., and Schultz, C.L., 2005, Early Triassic temnospondyl skull fragments from southern South America (Paraná Basin, Brazil): Revista Brasileira de Paleontologia, v. 8, p. 165-172.

Dias-da-Silva, S., Marsicano, C., and Schultz, C.L., 2006, Rhytidosteid temnospondyls in Gondwana: a new taxon from the Lower Triassic of Brazil: Palaeontology, v. 49, p. 381-390, https://doi.org/10.1111/j.1475-4983.2006. 00545.x.

Dutuit, J.M., 1976, Introduction à l'étude paléontologique du Trias continental Marocain. Description des premiers stegocephales recueillis dans le couloir d'Argana (Atlas occidental): Memoires du Museum National d'Histoire naturelle, Paris, Series C, v. 36, p. 1-253.

Efremov, I.A., 1929, Benthosaurus sushkini, ein neuer Labyrinthodont der permotriasischen Ablagerungen des Scharschenga Flusses, Nord-Düna Gouvernment: Bulletin del'Academie des Sciences de l'Union des Republiques Sovietiques Socialistes, Math and Natural Sciences, v. 1929 p. 757-770.

Eltink, E., and Langer, M.C., 2014, A new specimen of the temnospondyl Australerpeton cosgriffi from the late Permian of Brazil (Rio do Rasto Formation, Paraná Basin): comparative anatomy and phylogenetic relationships: Journal of Vertebrate Paleontology, v. 34, p. 524-538, https://doi.org/10 1080/02724634.2013.826667.

Eltink, E., Dias, E.V., Dias-da-Silva, S., Schultz, C.L., and Langer, M.C., 2016, The cranial morphology of the temnospondyl Australerpeton cosgriffi (Tetrapoda: Stereospondyli) from the Middle-Late Permian of Paraná Basin and the phylogenetic relationships of Rhinesuchidae: Zoological Journal of the Linnean Society, v. 176, p. 835-860, https:// doi.org/10.1111/zoj.12339.

Eltink, E., Schoch, R.R., and Langer, M.C., 2019, Interrelationships, palaeobiogeography and early evolution of Stereospondylomorpha (Tetrapoda: Temnospondyli): Journal of Iberian Geology, v. 45, p. 251-267, https://doi.org/ $10.1007 / \mathrm{s} 41513-019-00105-\mathrm{z}$.

Englehorn, J., Small, B.J., and Huttenlocker, A., 2008, A redescription of Acroplous vorax (Temnospondyli: Dvinosauria) based on new specimens from the Early Permian of Nebraska and Kansas, USA: Journal of Vertebrate Paleontology, v. 28, p. 291-305, https://doi.org/10.1671/0272-4634(2008) 28[291:AROAVT]2.0.CO;2.

Fraas, E., 1913, Neue Labyrinthodonten aus der schwäbischen Trias: Palaeontographica, v. 60, p. 275-294.

Foreman, B.C., 1990, A revision of the cranial morphology of the lower Permian temnospondyl amphibian Acroplous vorax Hotton: Journal of Vertebrate Paleontology, v. 10, p. 390-397, https://doi.org/10.1080/02724634. 1990.10011822.

Fröbisch, N.B., and Reisz, R.R., 2008, A new Lower Permian amphibamid (Dissorophoidea, Temnospondyli) from the fissure fill deposits near Richards Spur, Oklahoma: Journal of Vertebrate Paleontology, v. 28, p. 10151030, https://doi.org/10.1671/0272-4634-28.4.1015.

Gee, B.M., and Sidor, C.A., 2021, First record of the amphibamiform Micropholis stowi from the lower Fremouw Formation (Lower Triassic) of Antarctica: Journal of Vertebrate Paleontology, v. 41, e1904251, https://doi.org/10. 1080/02724634.2021.1904251. 
Geinitz, H.B., 1862, Dyas oder die Zechsteinformation und das Rothliegende, Permische Formation zum Theil: Leipzig, W. Engelmann, Theile 1-18, $342 \mathrm{p}$.

Getmanov, S.N., 1989, Triassic amphibians of the East European platform (family Benthosuchidae Efremov): Trudy Paleontologicheskogo Instituta, v. 236, p. 1-102.

Goldfuß, A., 1847, Beiträge zur vorweltlichen Fauna des Steinkohlengebirges: Bonn, Henry \& Cohen, 28 p.

Golubev, V.K., 1995. New species of Melosaurus (Amphibia, Labyrinthodontia) from the Kazanian of the Kama River drainage area: Paleontologicheskii Zhurnal, v. 29, p. 107-119.

Gubin, Y.M., 1991, Permian archegosauroid amphibians of the USSR: Trudy Paleontologicheskogo Instituta, Akademiya Nauk SSSR, v. 249, p. $1-138$.

Hewison, R.H., 1996, The skull of Deltacephalus whitei, a lydekkerinid temnospondyl amphibian from the Lower Triassic of Madagascar: Palaeontology, v. 39, p. 305-322, https://www.palass.org/publications/palaeontology-journal/archive/39/2/article pp305-321.

Hewison, R.H., 2007, Journal of Temnospondyl Palaeontology, Volume 1. The skull and mandible of the stereospondyl Lydekkerina huxleyi, (Tetrapoda: Temnospondyli) from the Lower Triassic of South Africa, and a reappraisal of the family Lydekkerinidae, its origin, taxonomic relationships and phylogenetic importance: Somerset, Dorset, UK, R.H. Hewison [self-published], v. 1, 80 p., http://www.lydekkerina.com/images/Vol\%201\%20Number\% 201.pdf.

Hewison, R.H., 2008, Journal of Temnospondyl Palaeontology, Volume 2. The sacral region, pelvis and hind limb of the stereospondyl Lydekkerina huxleyi (Tetrapoda: Temnospondyli) from the Lower Triassic of South Africa: Somerset, Dorset, UK, R.H. Hewison [self-published], 31 p., http://www.lydekkerina.com/images/Vol\%202\%20Number\%201-1.pdf.

Howie, A.A., 1972, On a Queensland labyrinthodont, in Joysey, K.A., and Kemp, T.S., eds., Studies in Vertebrate Evolution: Edinburgh, UK, Oliver Boyd, p. 50-64.

Hunt, A.P., 1993, Revision of the Metoposauridae (Amphibia: Temnospondyli) and description of a new genus from western North America: Museum of Northern Arizona, Bulletin, v. 59, p. 67-97.

Huxley, T.H., 1859, On some amphibian and reptilian remains from South Africa and Australia: Quarterly Journal of the Geological Society, v. 15, p. 642-658, https://doi.org/10.1144/GSL.JGS.1859.015.01-02.71.

International Commission on Zoological Nomenclature (ICZN), 1999, International Code of Zoological Nomenclature ( $4^{\text {th }}$ Edition): London, International Trust for Zoological Nomenclature.

Jaeger, G.F. von, 1828, Ueber die Fossile Reptilien Welche in Württemberg Auffgefunden Worden Sind: Stuttgart, Metzler, 48 p.

Jeannot, A.M., Damiani, R., and Rubidge, B.S., 2006, Cranial anatomy of the Early Triassic stereospondyl Lydekkerina huxleyi (Tetrapoda: Temnospondyli) and the taxonomy of South African lydekkerinids: Journal of Vertebrate Paleontology, v. 26, p. 822-838, https://doi.org/10.1671/0272-4634 (2006)26[822:CAOTET]2.0.CO;2.

Kathe, W., 1999, Comparative morphology and functional interpretation of the sutures in the dermal skull roof of temnospondyl amphibians: Zoological Journal of the Linnean Society, v. 126, p. 1-39, https://doi.org/10.1111/j. 1096-3642.1999.tb00605.x.

Kitching, J.W., 1958, A new small stereospondylous labyrinthodont from the Triassic beds of South Africa: Palaeontologia Africana, v. 5, p. 67-82, http://hdl.handle.net/10539/16072.

Kitching, J.W., Collinson, J.W., Elliot, D.H., and Colbert, E.H., 1972, Lystrosaurus Zone (Triassic) fauna from Antarctica: Science, v. 175, p. 524-527, https://doi.org/10.1126/science.175.4021.524.

Lehman, J.-P., 1961, Les stégocephales de Madagascar: Annales de Paléontologie, v. 47, p. $42-46$.

Lehman, J.-P., 1966, Nouveaux stégocéphales de Madagascar: Annales de Paléontologie, v. 52, p. 115-139.

Lydekker, R., 1889, Note on the occurrence of a species of Bothriceps in the Karroo system of South Africa: Annals and Magazine of Natural History, v. 4, p. 475-476, https://doi.org/10.1080/00222938909460569.

Maddin, H.C., Fröbisch, N.B., Evans, D.C., and Milner, A.R., 2013, Reappraisal of the early Permian amphibamid Tersomius texensis and some referred material: Comptes Rendus Palevol, v. 12, p. 447-461, https://doi.org/10.1016/j.crpv.2013.06.007.

Maganuco, S., Steyer, J.-S., Pasini, G., Boulay, M., Lorrain, S., Bénéteau, A., and Auditore, M., 2009. An exquisite specimen of Edingerella madagascariensis (Temnospondyli) from the Lower Triassic of NW Madagascar; cranial anatomy, phylogeny, and restorations: Memorie della Società Italiana di Scienze Naturalie del Museo Civico di Storia Naturale di Milano, v. 36, p. $1-72$.

Marsicano, C.A., and Warren, A., 1998, The first Palaezoic rhytidosteid: Trucheosaurus major (Woodward, 1909) from the late Permian of Australia, and a reassessment of the Rhytidosteidae (Amphibia, Temnospondyli):
Bulletin of the British Museum (Nautral History) Geology, v. 54, p. 147-154.

Marsicano, C.A., Latimer, E., Rubidge, B., and Smith, R.M., 2017, The Rhinesuchidae and early history of the Stereospondyli (Amphibia: Temnospondyli) at the end of the Palaeozoic: Zoological Journal of the Linnean Society, v. 181, p. 357-384, https://doi.org/10.1093/zoolinnean/zlw032.

McHugh, J.B., 2012, Temnospondyl ontogeny and phylogeny, a window into terrestrial ecosystems during the Permian-Triassic mass extinction [Ph.D. dissertation]: Iowa City, The University of Iowa, 198 p., https://doi.org/ 10.17077/etd.bckqmevc .

McHugh, J.B., 2015, Paleohistology of Micropholis stowi (Dissorophoidea) and Lydekkerina huxleyi (Lydekkerinidae) humeri from the Karoo Basin of South Africa, and implications for bone microstructure evolution in temnospondyl amphibians: Journal of Vertebrate Paleontology, v. 35, e902845, https://doi.org/10.1080/02724634.2014.902845.

Milner, A.R., and Sequeira, S.E.K., 1993, The temnospondyl amphibians from the Viséan of east Kirkton, West Lothian, Scotland: Earth and Environmental Science Transactions of the Royal Society of Edinburgh, v. 84, p. 331-361, https://doi.org/10.1017/S0263593300006155.

Milner, A.R., and Sequeira, S.E.K., 2011, The amphibian Erpetosaurus radiatus (Temnospondyli, Dvinosauria) from the Middle Pennsylvannian of Linton, Ohio: morphology and systematic variation: Special Papers in Palaeontology, v. 86, p. 57-73.

Moodie, R.L., 1909, New or little known forms of Carboniferous Amphibia in the American Museum of Natural History: Bulletin of the American Museum of Natural History, v. 26, p. 347-357, http://hdl.handle.net/2246/ 1450 .

Morkovin, B.I., 2015, On the development of surface ornamentation of skull bones in the ontogeny of Early Triassic benthosuchids (Amphibia, Temnospondyli): Paleontological Journal, v. 49, p. 57-69, https://doi.org/10.1134/ S0031030115010074.

Mukherjee, R.N., and Sengupta, D.P., 1998. New capitosaurid amphibians from the Triassic Denwa Formation of the Satpura Gondwana Basin, central India: Alcheringa, v. 22, p. 317-327, https://doi.org/10.1080/ 03115519808619330.

Pardo, J.D., Small, B.J., and Huttenlocker, A.K., 2017, Stem caecilian from the Triassic of Colorado sheds light on the origins of Lissamphibia: Proceedings of the National Academy of Sciences, v. 114, p. E5389-E5395, https://doi. org/10.1073/pnas.1706752114.

Parrington, F.R., 1935, XVI.-On Prolacerta broomi, gen. et sp. n., and the origin of lizards: Annals and Magazine of Natural History, 16, 197-205, https://doi.org/10.1080/00222933508655037.

Parrington, F.R., 1948, Labyrinthodonts from South Africa: Proceedings of the Zoological Society of London, v. 118, p. 426-446, https://doi.org/10.1111/ j.1096-3642.1948.tb00388.x.

Pawley, K., and Warren, A.A., 2004, Immaturity vs paedomorphism: a rhinesuchid stereospondyl postcranium from the Upper Permian of South Africa: Palaeontologia Africana, v. 40, p. 1-10, http://hdl.handle.net/ 10539/15971.

Pawley, K., and Warren, A., 2005, A terrestrial stereospondyl from the Lower Triassic of South Africa: the postcranial skeleton of Lydekkerina huxleyi (Amphibia: Temnospondyli): Palaeontology, v. 48, p. 281-298, https:// doi.org/10.1111/j.1475-4983.2005.00446.x.

Peecook, B.R., Smith, R.M.H., and Sidor, C.A., 2019, A novel archosauromorph from Antarctica and an updated review of a high-latitude vertebrate assemblage in the wake of the end-Permian mass extinction. Journal of Vertebrate Paleontology, v. 38, e1536664, https://doi.org/10.1080/02724634. 2018.1536664.

Pérez-Ben, C.M., Schoch, R.R., and Báez, A.M., 2018, Miniaturization and morphological evolution in Paleozoic relatives of living amphibians: a quantitative approach: Paleobiology, v. 44, p. 58-75, https://doi.org/10.1017/ pab.2017.22.

Pérez-Ben, C.M., Báez, A.M., and Schoch, R.R., 2019 [for 2020], Morphological evolution of the skull roof in temnospondyl amphibians mirrors conservative ontogenetic patterns: Zoological Journal of the Linnean Society, v. 188, p. 163-179, https://doi.org/10.1093/zoolinnean/zlz068.

Piñeiro, G., Ramos, A., and Marsicano, C., 2012, A rhinesuchid-like temnospondyl from the Permo-Triassic of Uruguay: Comptes Rendus Palevol, v. 11 , p. $65-78$, https://doi.org/10.1016/j.crpv.2011.07.007.

Ramos, B.D., and Vega, C.S., 2011, Temnospondyl remains from the late Permian Rio do Rasto Formation (Paraná Basin) of Brazil: Revista Brasileira de Paleontologia, v. 14, p. 67-74, https://doi.org/10.4072/rbp.2011.1.07.

Romer, A.S., 1947, Review of the Labyrinthodontia: Bulletin of the Museum of Comparative Zoology, v. 99, p. 1-367.

Romer, A.S., 1969, A temnospondylous labyrinthodont from the Lower Carboniferous: Kirtlandia, v. 6, p. 1-20.

Romer, A.S., 1970, A new anthracosaur labyrinthodont Proterogyrinus scheelei, from the Lower Carboniferous: Kirtlandia, v. 10, p. 1-16. 
Ruta, M., and Benton, M.J., 2008, Calibrated diversity, tree topology and the mother of mass extinctions: the lesson of temnospondyls: Palaeontology, v. 51, p. 1261-1288, https://doi.org/10.1111/j.1475-4983.2008.00808.x.

Ruta, M., Pisani, D., Lloyd, G.T., and Benton, M.J., 2007, A supertree of Temnospondyli: cladogenetic patterns in the most species-rich group of early tetrapods: Proceedings of the Royal Society B: Biological Sciences, v. 274, p. 3087-3095, https://doi.org/10.1098/rspb.2007.1250.

Säve-Söderbergh, G., 1935, On the dermal bones of the head in labyrinthodont stegocephalians and primitive Reptilia with special reference to Eotriassic stegocephalians from East Greenland: Meddelelserom Grønland, v. 98, p. $1-211$.

Schoch, R.R., 1995, Heterochrony in the development of the amphibian head, in McNamara, K.J., ed., Evolutionary Change and Heterochrony: New York, John Wiley and Sons, p. 107-124.

Schoch, R.R., 1999, Comparative osteology of Mastodonsaurus giganteus (Jaeger, 1828) from the Middle Triassic (Lettenkeuper: Longobardian) of Germany (Baden-Württemberg, Bayern, Thüringen): Stuttgarter Beiträge zur Naturkunde. Serie B, Geologie und Paläontologie, v. 278, p. $1-176$.

Schoch, R.R., 2000, The origin and intrarelationships of Triassic capitosaurid amphibians: Palaeontology, v. 43, p. 705-727, https://doi.org/10.1111/ $1475-4983.00146$.

Schoch, R.R., 2002, The neurocranium of the stereospondyl Mastodonsaurus giganteus: Palaeontology, v. 45, p. 627-645, https://doi.org/10.1111/ 1475-4983.00252.

Schoch, R.R., 2008a, A new stereospondyl from the German Middle Triassic, and the origin of the Metoposauridae: Zoological Journal of the Linnean Society, v. 152, p. 79-113, https://doi.org/10.1111/j.1096-3642.2007. 00363.x.

Schoch, R.R., 2008b, The Capitosauria (Amphibia): characters, phylogeny, and stratigraphy: Palaeodiversity, v. 1, p. 189-226.

Schoch, R.R., 2009, Evolution of life cycles in early amphibians: Annual Review of Earth and Planetary Sciences, v. 37, p. 135-162.

Schoch, R., 2010, Heterochrony: the interplay between development and ecology exemplified by a Paleozoic amphibian clade: Paleobiology, v. 36 p. 318-334.

Schoch, R.R., 2013, The evolution of major temnospondyl clades: an inclusive phylogenetic analysis: Journal of Systematic Palaeontology, v. 11, p. 673705, https://doi.org/10.1146/annurev.earth.031208.100113.

Schoch, R.R., 2014, Life cycles, plasticity and palaeoecology in temnospondyl amphibians: Palaeontology, v. 57, p. 517-529, https://doi.org/10.1111/pala. 12100 .

Schoch, R.R., 2018, Osteology of the temnospondyl Neldasaurus and the evolution of basal dvinosaurians: Neues Jahrbuch für Geologie und Paläontologie-Abhandlungen, v. 287, p. 1-16, https://doi.org/10.1127/ njgpa/2018/0700.

Schoch, R.R., 2019, Osteology of the temnospondyl Trematosaurus brauni Burmeister, 1849 from the Middle Buntsandstein of Bernburg, Germany: Palaeodiversity, v. 12, p. 41-63, https://doi.org/10.18476/pale.v12.a4.

Schoch, R.R., and Milner, A.R., 2000, Handbuch Der Paläoherpetologie: Teil 3B: Stereospondyli: München, Verlag Dr. Friedrich Pfeil, 220 p.

Schoch, R.R., and Milner, A.R., 2014, Handbuch Der Paläoherpetologie: Teil 3A2: Temnospondyli I: München, Verlag Dr. Friedrich Pfeil, 150 p.

Schoch, R.R., and Rubidge, B.S., 2005, The amphibamid Micropholis from the Lystrosaurus assemblage zone of South Africa: Journal of Vertebrate Paleontology, v. 25, p. 502-522, https://doi.org/10.1671/0272-4634(2005)025 [0502:TAMFTL]2.0.CO;2.

Schoch, R.R., and Voigt, S., 2019, A dvinosaurian temnospondyl from the Carboniferous-Permian boundary of Germany sheds light on dvinosaurian phylogeny and distribution: Journal of Vertebrate Paleontology, v. 39, e1577874, https://doi.org/10.1080/02724634.2019.1577874.

Schoch, R.R., and Witzmann, F., 2009a, Osteology and relationships of the temnospondyl genus Sclerocephalus: Zoological Journal of the Linnean Society, v. 157, p. 135-168, https://doi.org/10.1111/j.1096-3642.2009. 00535.x.

Schoch, R.R., and Witzmann, F., 2009b, The temnospondyl Glanochthon from the lower Permian Meisenheim Formation of Germany: Special Papers in Palaeontology, v. 81, p. 121-136.

Schoch, R.R., and Witzmann, F., 2012, Cranial morphology of the plagiosaurid Gerrothorax pulcherrimus as an extreme example of evolutionary stasis: Lethaia, v. 45, p. 371-385, https://doi.org/10.1111/j.1502-3931.2011. 00290.x.

Schoch, R.R., Werneburg, R., and Voigt, S., 2020, A Triassic stem-salamander from Kyrgyzstan and the origin of salamanders: Proceedings of the National Academy of Sciences, v. 117, p. 11584-11588, https://doi.org/10.1073/ pnas.2001424117.

Sequeira, S.E.K., 1998, The cranial morphology and taxonomy of the saurerpetontid Isodectes obtusus comb. nov.(Amphibia: Temnospondyli) from the Lower Permian of Texas: Zoological Journal of the Linnean
Society, v. 122, p. 237-259, https://doi.org/10.1111/j.1096-3642.1998. tb02531.x.

Shishkin, M.A., 1973, Morphology of ancient amphibians and problems of the evolution of lower tetrapods: Trudy Paleontologicheskogo Instituta Akademia Nauk SSSR, v. 137, p. 1-257.

Shishkin, M.A., 1980, The Luzocephalidae, a new Triassic labyrinthodont family: Paleontological Journal, v. 14, p. 88-101.

Shishkin, M.A., 1994, A Gondwana rhytidosteid (Amphibia, Temnospondyli) from the Lower Triassic of southern Cisuralia: Paleontological Journal, v. 28 , p. $127-143$

Shishkin, M.A., 2003, The patterns of evolution of Early Triassic herpetofauna in Europe and Gondwana: comparisons and implications, in Ananjeva, N., and Tsinenko, O., eds., Proceedings of the 12th Ordinary General Meeting of the Societas Europaea Herpetologica: St. Petersburg, Societas Europaea Herpetologica, p. 301-303.

Shishkin, M.A., 2007, Patterns of recovery of amphibian diversity in the Triassic: New Mexico Museum of Natural History and Science Bulletin, v. 41, p. 369-370.

Shishkin, M.A., and Rubidge, B.S., 2000, A relict rhinesuchid (Amphibia: Temnospondyli) from the Lower Triassic of South Africa: Palaeontology, v. 43, p. $653-670$, https://doi.org/10.1111/1475-4983.00144.

Shishkin, M.A., and Welman, J., 1994, A new find of Trematosuchus (Amphibia, Temnospondyli) from the Cynognathus Zone of South Africa: Palaeontologia Africana, v. 31, p. 39-49, http://hdl.handle.net/10539/16277.

Shishkin, M.A., Rubidge, B.S., and Kitching, J.W., 1996, A new lydekkerinid (Amphibia, Temnospondyli) from the Lower Triassic of South Africa: implications for evolution of the early capitosauroid cranial pattern: Philosophical Transactions of the Royal Society of London. Series B: Biological Sciences, v. 351, p. 1635-1659, https://doi.org/10.1098/rstb.1996.0147.

Shishkin, M.A., Sennikov, A.G., Novikov, I.V., and Ilyina, N.V., 2006, Differentiation of tetrapod communities and some aspects of biotic events in the Early Triassic of Eastern Europe: Paleontological Journal, v. 40, p. 1-10.

Sidor, C.A., Steyer, J.-S., and Damiani, R., 2007, Parotosuchus (Temnospondyli: Mastodonsauridae) from the Triassic of Antarctica: Journal of Vertebrate Paleontology, v. 27, p. 232-235, https://doi.org/10.1671/0272-4634 (2007)27[232:PTMFTT]2.0.CO;2.

Sidor, C.A., Damiani, R., and Hammer, W.R., 2008, A new Triassic temnospondyl from Antarctica and a review of Fremouw Formation biostratigraphy: Journal of Vertebrate Paleontology, v. 28, p. 656-663, https://doi org/10.1671/0272-4634(2008)28[656:ANTTFA]2.0.CO;2.

Sidor, C.A., Steyer, J.-S., and Hammer, W.R., 2014, A new capitosauroid temnospondyl from the Middle Triassic upper Fremouw Formation of Antarctica: Journal of Vertebrate Paleontology, v. 34, p. 539-548, https://doi org/10.1080/02724634.2013.808205

Sigurdsen, T., and Bolt, J.R., 2010, The Lower Permian amphibamid Doleserpeton (Temnospondyli: Dissorophoidea), the interrelationships of amphibamids, and the origin of modern amphibians: Journal of Vertebrate Paleontology, v. 30, p. 1360-1377, https://doi.org/10.1080/02724634 2010.501445

Stephens, W.J., 1887, On some additional labyrinthodont fossils from the Hawkesbury sandstones of New South Wales: Proceedings of the Linnean Society of New South Wales, v. 2, p. 1175-1192.

Steyer, J.-S., 1996, Readaptation to the aquatic environment and developmental heterochronies in the eryopoids (Amphibia, Temnospondyli), in Mazin, J.M., Vignaud, P., and de Buffrenil, V., eds., Secondary Adaptation to Life in Water: Poitiers, France, Poitiers University Press, p. 82-83.

Steyer, J.-S., 2000, Ontogeny and phylogeny in temnospondyls: a new method of analysis: Zoological Journal of the Linnean Society, v. 130, p. v. 449467, https://doi.org/10.1111/j.1096-3642.2000.tb01637.x.

Steyer, J.-S., 2003, A revision of the early Triassic "capitosaurs" (Stegocephali, Stereospondyli) from Madagascar, with remarks on their comparative ontogeny: Journal of Vertebrate Paleontology, v. 23, p. 544-555, https:// doi.org/10.1671/1740.

Swinton, W.E., 1956, A neorhachitome amphibian from Madagascar: Annals and Magazine of Natural History, v. 9, p. 60-64, https://doi.org/10.1080/ 00222935608655722.

Swofford, D.L., 2002, PAUP*: Phylogenetic Analysis Using Parsimony (and other methods) ver. 4.0.b169: University of Florida, http://paup.phylosolutions.com/.

Tarailo, D.A., 2018, Taxonomic and ecomorphological diversity of temnospondyl amphibians across the Permian-Triassic boundary in the Karoo Basin (South Africa): Journal of Morphology, v. 279, p. 1840-1848, https://doi. org/10.1002/jmor.20906

Van Hoepen E.C.N., 1911, Korte voorlopige beschrijving van te Senekal gevonden stegocephalen: Annals of the Transvaal Museum, v. 3, p. 102 106, https://hdl.handle.net/10520/AJA00411752 885.

Warren, A.A., 1980, Parotosuchus from the Early Triassic of Queensland and Western Australia: Alcheringa, v. 4, p. 25-36, https://doi.org/10.1080/ 03115518008558978. 
Warren, A., 1998a, Karoo tupilakosaurid: a relict from Gondwana: Earth and Environmental Science Transactions of The Royal Society of Edinburgh, v. 89, p. 145-160, https://doi.org/10.1017/S0263593300007094.

Warren, A., 1998b, Laidleria uncovered: a redescription of Laidleria gracilis Kitching (1957), a temnospondyl from the Cynognathus Zone of South Africa: Zoological Journal of the Linnean Society, v. 122, p. 167-185, https://doi.org/10.1111/j.1096-3642.1998.tb02528.x.

Warren, A., 2012, The South African stereospondyl Microposaurus from the Middle Triassic of the Sydney Basin, Australia: Journal of Vertebrate Paleontology, v. 32, p. 538-544, https://doi.org/10.1080/02724634.2012. 658934.

Warren, A., and Black, T., 1985, A new rhytidosteid (Amphibia, Labyrinthodontia) from the Early Triassic Arcadia Formation of Queensland, Australia, and the relationships of Triassic temnospondyls: Journal of Vertebrate Paleontology, v. 5, p. 303-327, https://doi.org/10.1080/02724634.1985. 10011868.

Warren, A.A., and Hutchinson, M.N., 1987, The skeleton of a new hornless rhytidosteid (Amphibia, Temnospondyli): Alcheringa, v. 11, p. 291-302, https://doi.org/10.1080/03115518708619138.

Warren, A.A., and Hutchinson, M.N., 1988, A new capitosaurid amphibian from the Early Triassic of Queensland, and the ontogeny of the capitosaur skull: Palaeontology, v. 31, p. 857-876, https://www.palass.org/publications/palaeontology-journal/archive/31/3/article_pp857-876.

Warren, A.A., and Hutchinson, M.N., 1990a, Lapillopsis, a new genus of temnospondyl amphibians from the Early Triassic of Queensland: Alcheringa, v. 14, p. 149-158, https://doi.org/10.1080/03115519008527816.

Warren, A.A., and Hutchinson, M.N., 1990b, The young ones-small temnospondyls from the Arcadia Formation: Memoirs of the Queensland Museum, v. 28 , p. $103-106$.

Warren, A., and Marsicano, C., 1998, Revision of the Brachyopidae (Temnospondyli) from the Triassic of the Sydney, Carnarvon and Tasmania basins, Australia: Alcheringa, v. 22, p. 329-342, https://doi.org/10.1080/ 03115519808619331.

Warren, A., and Marsicano, C., 2000, A phylogeny of the Brachyopoidea (Temnospondyli, Stereospondyli): Journal of Vertebrate Paleontology, v. 20, p. 462-483, https://doi.org/10.1671/0272-4634(2000)020[0462:APOTBT] 2.0.CO;2.

Warren, A.A., and Schroeder, N., 1995, Changes in the capitosaur skull with growth: an extension of the growth series of Parotosuchus aliciae (Amphibia, Temnospondyli) with comments on the otic area of capitosaurs: Alcheringa, v. 19, p. 41-46, https://doi.org/10.1080/03115519508619097.

Warren, A.A., Damiani, R., and Yates, A.M., 2006. The South African stereospondyl Lydekkerina huxleyi (Tetrapoda, Temnospondyli) from the Lower Triassic of Australia: Geological Magazine, v. 143, p. 877-886, https:// doi.org/10.1017/S0016756806002524.

Watson, D.M.S., 1919, I. The structure, evolution and origin of the Amphibia.-The "orders' [sic] Rachitomi and Stereospondyli: Philosophical Transactions of the Royal Society of London. Series B, Containing Papers of a Biological Character, v. 209, p. 1-73, https://doi.org/10.1098/ rstb.1920.0001.

Watson, D.M.S., 1962, The evolution of the labyrinthodonts: Philosophical Transactions of the Royal Society of London. Series B, Biological Sciences, v. 245 , p. 219-265, https://doi.org/10.1098/rstb.1962.0010.

Welles, S.P., and Cosgriff, J., 1965, A revision of the labyrinthodont family Capitosauridae: University of California Publications in Geological Sciences, v. 54, p. 1-147.
Witzmann, F., 2005, Cranial morphology and ontogeny of the PermoCarboniferous temnospondyl Archegosaurus decheni Goldfuss, 1847 from the Saar-Nahe Basin, Germany: Earth and Environmental Science Transactions of The Royal Society of Edinburgh, v. 96, p. 131-162, https://doi.org/10.1017/S0263593300001279.

Witzmann, F., 2006, Developmental patterns and ossification sequence in the Permo-Carboniferous temnospondyl Archegosaurus decheni (Saar-Nahe Basin, Germany): Journal of Vertebrate Paleontology, v. 26, p. 7-17, https://doi.org/10.1671/0272-4634(2006)26[7:DPAOSI]2.0.CO;2.

Witzmann, F., and Pfretzschner, H.U., 2003, Larval ontogeny of Micromelerpeton credneri (Temnospondyli, Dissorophoidea): Journal of Vertebrate Paleontology, v. 23, p. 750-768, https://doi.org/10.1671/3.

Witzmann, F., and Schoch, R.R., 2005, Skeletal development of the temnospondyl Acanthostomatops vorax from the Lower Permian Döhlen Basin of Saxony: Earth and Environmental Science Transactions of the Royal Society of Edinburgh, v. 96, p. 365-385, https://doi.org/10.1017/ S0263593300001358.

Witzmann, F., and Scholz, H., 2007, Morphometric study of allometric skull growth in the temnospondyl Archegosaurus decheni from the Permian/Carboniferous of Germany: Geobios, v. 40, p. 541-554, https://doi.org/10. 1016/j.geobios.2006.07.001.

Witzmann, F., Scholz, H., and Ruta, M., 2009, Morphospace occupation of temnospondyl growth series: a geometric morphometric approach: Alcheringa, v. 33, p. 237-255, https://doi.org/10.1080/03115510903043606.

Witzmann, F., Scholz, H., Mueller, J., and Kardjilov, N., 2010, Sculpture and vascularization of dermal bones, and the implications for the physiology of basal tetrapods: Zoological Journal of the Linnean Society, v. 160, p. 302-340, https://doi.org/10.1111/j.1096-3642.2009.00599.x.

Witzmann, F., Schoch, R.R., Hilger, A., and Kardjilov, N., 2012, Braincase, palatoquadrate and ear region of the plagiosaurid Gerrothorax pulcherrimus from the Middle Triassic of Germany: Palaeontology, v. 55, p. 31-50, https://doi.org/10.1111/j.1475-4983.2011.01116.x.

Woodward, A.S., 1891, VI.-On a microsaurian (Hylonomus Wildi, sp. nov.) from the Lancashire Coal-field: Geological Magazine, v. 8, p. 211-213, https://doi.org/10.1017/S0016756800187862.

Yates, A.M., 1999, The Lapillopsidae: a new family of small temnospondyls from the Early Triassic of Australia: Journal of Vertebrate Paleontology, v. 19, p. 302-320, https://doi.org/10.1080/02724634.1999.10011143.

Yates, A.M., 2000, A new tiny rhytidosteid (Temnospondyli: Stereospondyli) from the Early Triassic of Australia and the possibility of hidden temnospondyl diversity: Journal of Vertebrate Paleontology, v. 20, p. 484-489, https:// doi.org/10.1671/0272-4634(2000)020[0484:ANTRTS]2.0.CO;2.

Yates, A.M., and Sengupta, D.P., 2002, A lapillopsid temnospondyl from the Early Triassic of India: Alcheringa, v. 26, p. 201-208, https://doi.org/10. 1080/03115510208619252.

Yates, A.M., and Warren, A.A., 2000, The phylogeny of the 'higher'temnospondyls (Vertebrata: Choanata) and its implications for the monophyly and origins of the Stereospondyli: Zoological Journal of the Linnean Society, v. 128, p. 77-121, https://doi.org/10.1111/j.1096-3642.2000.tb00650.x.

Zittel, K.A., von, 1887-1890, Handbuch der Paläeontologie. Abteilung 1. Paläozoologie. Band III. Vertebrata (Pisces, Amphibia, Reptilia, Aves): Münich and Leipzig, Oldenbourg, 900 p.

Accepted: 14 November 2021 